\title{
A CHRONOLOGY OF THE SCYTHIAN ANTIQUITIES OF EURASIA BASED ON NEW ARCHAEOLOGICAL AND ${ }^{14} \mathrm{C}$ DATA
}

\author{
A Yu Alekseev ${ }^{1} \cdot \mathrm{N}$ A Bokovenko ${ }^{2} \bullet \mathrm{Yu} \mathrm{Boltrik}^{3} \bullet \mathrm{K} \mathrm{A} \mathrm{Chugunov}^{4} \bullet \mathrm{G} \mathrm{Cook}^{5} \bullet$ V A Dergachev 6

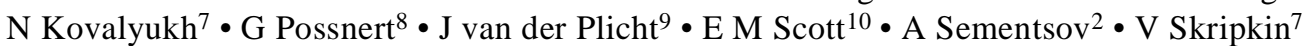 \\ $\mathrm{S}$ Vasiliev ${ }^{6} \cdot \mathrm{G}_{\text {Zaitseva }}{ }^{2}$
}

\begin{abstract}
The paper is compares the chronology of the monuments of the Scythian epoch located in the east and west of the Eurasian steppe zone on the basis of both archaeological and radiocarbon data. The lists of ${ }^{14} \mathrm{C}$ dates for the monuments located in different parts of Eurasia are presented according to the periods of their existence. Generally, the ${ }^{14} \mathrm{C}$ dates are confirmed the archaeological point of view and allow us to compare the chronological position of the European and Asian Scythian monuments on the united ${ }^{14} \mathrm{C}$ time scale.
\end{abstract}

\section{INTRODUCTION}

The chronology of the Scythian cultures which occupied the steppe and forest-steppe zones of Eurasia from Northern China to the River Danube during the 1st millennium BC, is very important. The beginning of the Scythian epoch in Eurasia has not been well established and also appears to start at different times in the western and eastern parts of the steppe belt. The inability to establish precisely the genesis of these striking and distinctive cultures is caused in part by the different approaches taken to construct the chronologies for the European and Asian Scythian cultures. For a long time, the chronology of the European Scythian cultures was based on typological comparisons and historical sources, while for the Asian Scythian cultures, radiocarbon dating played an important role. It is only relatively recently that the first ${ }^{14} \mathrm{C}$ dates were produced for European Scythian monuments. As a result, it has become possible to compare the chronological position of these cultures in Europe and Asia on a unified ${ }^{14} \mathrm{C}$ time scale.

This article summarizes and compares the results of research based on archaeological and ${ }^{14} \mathrm{C}$ data with special attention paid to key monuments and to the definition of a preliminary chronology.

\section{RESULTS}

Figure 1 shows the spread of cultures belonging to the Scythian epoch and the boundaries of different landscape zones. Most sites are located between $\sim 40^{\circ}-55^{\circ} \mathrm{N}$ and $30^{\circ}-110^{\circ} \mathrm{E}$ (the figure also includes those sites which have been ${ }^{14} \mathrm{C}$ dated).

As a result of research, Scythian history can be subdivided into three periods: 1st period-a preScythian and initial Scythian epoch from the 9th to middle of the 7th centuries BC, 2nd period-an early Scythian epoch from the 7th to the 6th centuries BC, and 3rd period-the classical Scythian

\footnotetext{
${ }^{1}$ The State Hermitage Museum, 191186 St. Petersburg, Russia. Email: oaves@hermitage.ru.

${ }^{2}$ The Institute of the History of Material Culture of Russian Academy of Sciences, 191186 St.Petersburg, Russia

${ }^{3}$ The Institute of Archaeology of the National Academy of Sciences of Ukraine, 254655 Kiev, Ukraine

${ }^{4}$ The Institute of Cultural and Natural Heritage,191011 St. Petersburg, Russia

${ }^{5}$ Radiocarbon Laboratory, SUERC, East Kilbride, Scotland

${ }^{6}$ The Physical-Technical Institute of the Russian Academy of Sciences, 194021 St. Petersburg, Russia

${ }^{7}$ State Scientific Centre of Environmental Radiochemistry of National Academy of Sciences of Ukraine, $252680 \mathrm{Kiev}$, Ukraine

${ }^{8}$ Radiocarbon Laboratory of Uppsala University, Uppsala, Sweden

${ }^{9}$ Radiocarbon Laboratory of Groningen University, Groningen, the Netherlands

${ }^{10}$ Department of Statistics, University of Glasgow, Glasgow, Scotland
}

(C) 2001 by the Arizona Board of Regents on behalf of the University of Arizona RadIOCARBON, Vol 43, Nr 2B, 2001, p 1085-1107

Proceedings of the 17 th International ${ }^{14} \mathrm{C}$ Conference, edited by I Carmi and E Boaretto 
epoch from the 5th to the 4th centuries BC. Here we will consider separately the current state of chronological research for each period based on archaeological evidence and ${ }^{14} \mathrm{C}$ dating. The archaeological evidence is based on the following approaches:

a) Typology, based on the dating of artifacts (smart prestige objects, wares, harness elements, objects of "animal style" and so on).

b) Dating of imported Greek ceramic and amphorae based mainly on the amphorae's brands.

c) Historical-biographical methods (from written histories).

d) Space-stratigraphical methods.

As the result of these approaches, a series of key monuments was determined. In the following sections, the chronological position of the different Scythian monuments located in the west and east of the Great Eurasian Steppe will be compared.

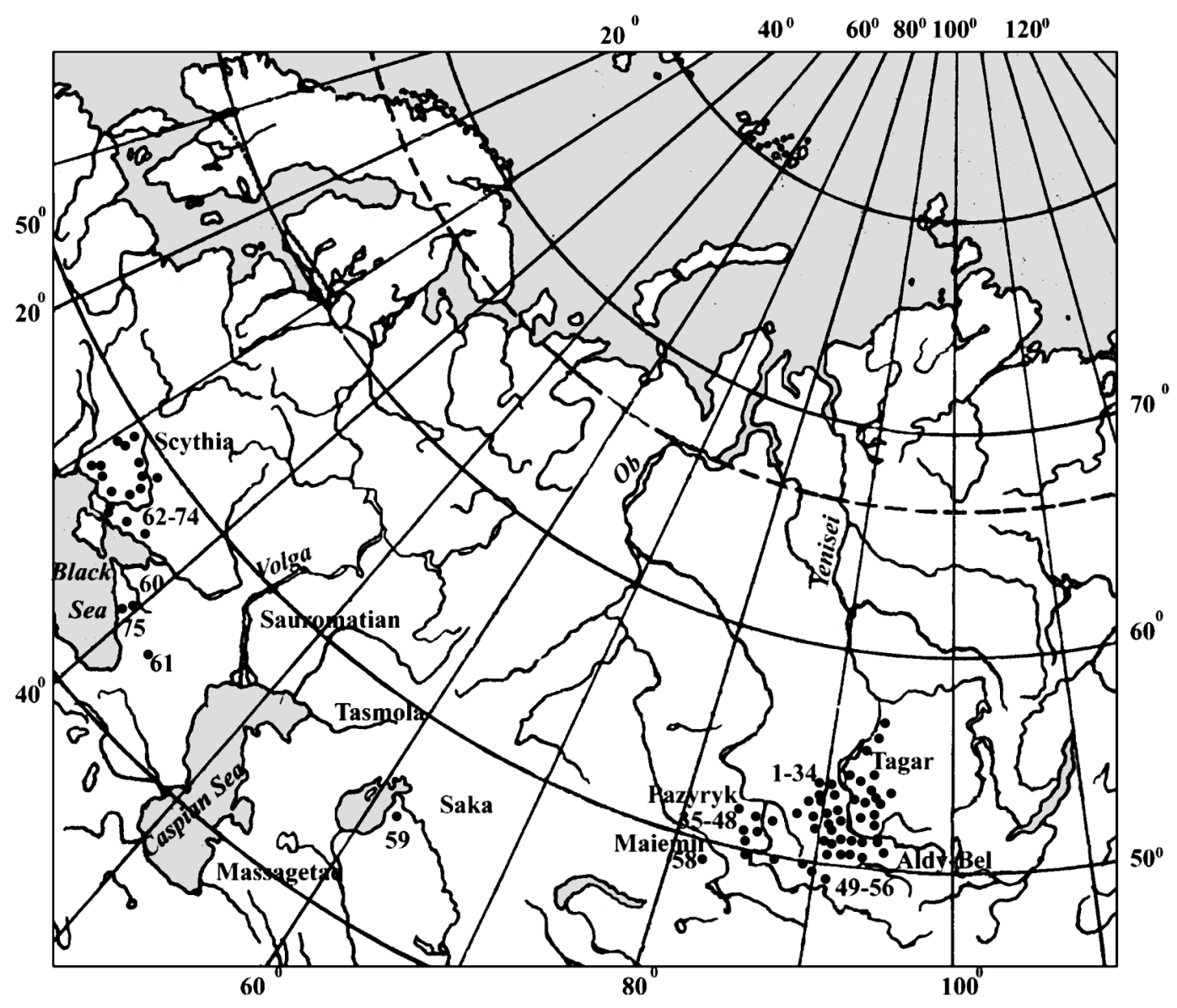

Figure 1 Locations of the Scythian epoch monuments in Eurasia dated by ${ }^{14} \mathrm{C} . \bullet=$ sites dated by ${ }^{14} \mathrm{C} .1-75=$ number of the monument in Tables 1-3. 


\section{Pre-Scythian and Initial Scythian Epoch (9th to 7th Centuries BC)}

\section{Archaeological Data}

The most famous Scythian monument in Central Asia (Tuva Republic) is the Arzhan barrow, which was discovered by M P Gryaznov (1980) in the 1970s. It is the key monument of the early Scythian epoch for all Eurasia. There are two main opinions on its chronology. According to the first, this monument dates to the 9th century BC (Bokovenko 1996; Zaitseva et al. 1997; Sher 1998) or to the 8th century BC (Gryznov 1980, 1983; Grach 1983). According to the second view, this monument dates to the 7th century BC (Kyzlasov 1977; Chlenova 1996, 1997). Undisputed, however, is that the Arzhan barrow is the earliest monument of the Scythian type in Central Asia. The specific details of its tomb construction, the complicated burial tradition, the perfection of the weapon's features, horse equipment, and artifacts would suggest the existence of an earlier stage in the formation of the Scythian-type cultures for this region in the 10th-9th centuries BC (Bokovenko 1992, 1994).

The monuments of the early Tagar culture of Southern Siberia are closely connected to the Central Asian antiquities and include among them the Khystaglar, Bol'shaya Erba, Kazanovka-3, and Shaman Gora barrows. For a long time these monuments have been traditionally dated to the 7th century BC (Kiselev 1949; Chlenova 1967). After the discovery of the Arzhan barrow, some archaeologists suggested dating the initial period of the Tagar culture to the 8th century BC (Kurochkin 1991; Bokovenko 1987). For dating the earliest stage of the Tagar culture, a most important role is played by the dates of the last stage of the Karasuk culture which preceded the Tagar culture and which belongs to the final stage of the Bronze Age. On the basis of the archaeological evidence, the final stage of the Karasuk culture existed in about the 10th century BC (Bokovenko 1996).

In the European part of the steppe, the pre-Scythian period is represented by the Chernogorovskaya culture (steppe zone of the Northern Black Sea region) and the antiquities of the Novocherkassk treasure discovered in 1939 (steppe zone of the Northern Black Sea region and the Northern Caucasus).

The chronology and the partial synchronization of these cultures have been confirmed by Klochko and Murzin (1980). They suggested the following chronological periods: the 10th to the beginning of 7th century BC for the Novocherkassk culture and the 9th to the middle of the 8th century BC for the Chernogorovskaya culture. There are other opinions on the chronology of these cultures. According to one such, it can be subdivided into three periods: 1) pre-Scythian period I, from the 9th to the first half of the 8th century BC (the Chernogorovsk type monuments), 2) pre-Scythian period II, from the middle to the end of the 8th century BC (the period of the co-existence of Chernogorovsk and Novocherkassk monuments), and 3) pre-Scythian period III, from the end of the 8th to the first half of the 7th century BC (the classical Novocherkassk monuments) (Dudarev 1995, 1998, 1999, 1999a). Alternatively, Kossack (1987) restricted the existence of the Novocherkassk-type monuments to the end of the 8th century BC. In all cases, the Chernogorovsk-type monuments are interpreted as being pre-Scythian, linked to a wave of nomads from the Eastern-Eurasia steppe zone who appeared in the Northern Black Sea region in about the 9th century BC (Klochko et al. 1997).

One of the key monuments of the pre-Scythian period in the European part of Eurasia is the Uashkhitu barrow in the Northern Caucasus which is related to the Novocherkassk culture and dated by archaeological evidence to the first half of the 7th century BC (Erlikh 1994).

The most ancient Scythian monument in Europe is considered to be barrow Nr 15 of the Steblev group of barrows located on the right bank of the River Dnieper in the forest-steppe zone. According to archaeological data, the artifacts from this barrow are similar to those in the Kazakhstan region and can be dated to the 8th century BC (Klochko and Skorii 1993). 


\section{${ }^{14}$ C Dating}

A ${ }^{14} \mathrm{C}$ chronology for this period has been developed for the monuments of Southern Siberia and the Central Asian regions. A number of ${ }^{14} \mathrm{C}$ dates were produced for the Arzhan barrow whose dating began with its discovery and continues until the present day. They are widely reported in the literature (Zaitseva et al. 1998a, 1998b; Dergachev et al. 2001). Currently, there are about $30{ }^{14} \mathrm{C}$ dates for this monument, confirming its existence at about the 9th-8th century BC. Comparison of the ${ }^{14} \mathrm{C}$ dates for the monuments of all Eurasia belonging to the 1st period is rather difficult because there was an unevenness in dating between European and Asian monuments. The monuments from the Asian territory contain more wooden remains suitable for ${ }^{14} \mathrm{C}$ dating. The dating of these monuments began in the 1960s and continues to the present day. Now there are about $40{ }^{14} \mathrm{C}$ dates, which are presented in Table 1. These dates confirm the age of the beginning of the Tagar culture (to the 7 th century $\mathrm{BC}$ ). Here only the most recent ${ }^{14} \mathrm{C}$ dates are presented for the European monuments.

The histogram of the distribution of the ${ }^{14} \mathrm{C}$ dates for the monuments investigated is presented in Figure 2. The ${ }^{14} \mathrm{C}$ dates for the Arzhan barrow were published earlier (Zaitseva et al. 1998a, 1998b). This histogram shows the co-existence of the Arzhan barrow and the pre-Scythian and Scythian monuments in Southern Siberia (Tagar culture). This fact does not contradict the appearance of the Tagar artifacts found in the Arzhan barrow.

The earlier Scythian monuments in Europe appeared some hundred years later. Unfortunately, the Chernogorovsk and Novocherkassk monuments have not been dated yet.

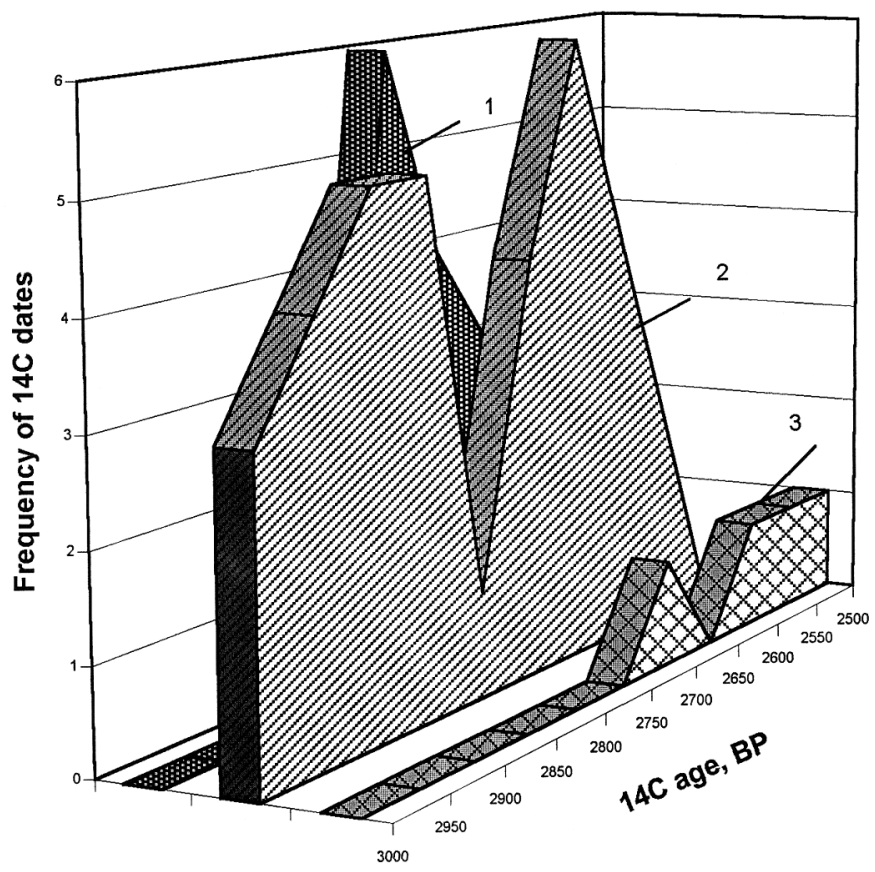

Figure 2 Histogram of the distribution of ${ }^{14} \mathrm{C}$ dates for the 1st period of the Scythian epoch: $1=$ the Arzhan barrow (Central Asia, Tuva Republic), $2=$ the barrows in Southern Siberia, $3=$ the European barrows. 


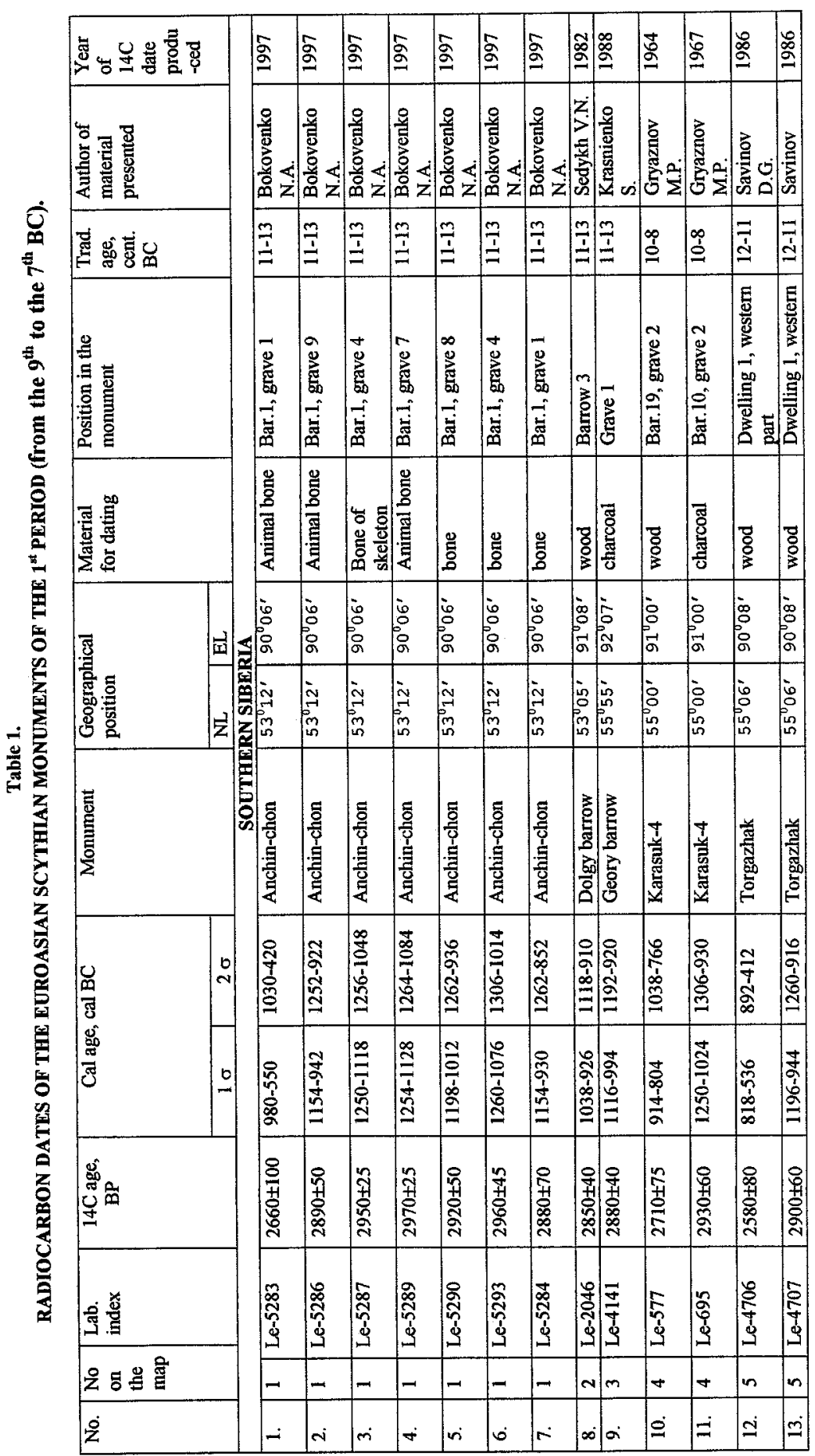




\begin{tabular}{|c|c|c|c|c|c|c|c|c|c|c|c|c|c|c|c|c|c|c|}
\hline 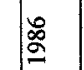 & 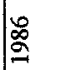 & 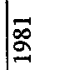 & Дี & $\cong$ & & & ळ & 就 & 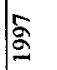 & פ & 梠 & $\hat{2}$ & ஓ & 20 & \% & $\begin{array}{l}2 \\
2 \\
2\end{array}$ & & ळ \\
\hline 10 & & & & & & & & 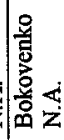 & 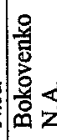 & 鄫 & 总 & 列 & | & 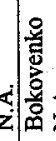 & 递 & 量 & & 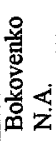 \\
\hline $\overrightarrow{\vec{\Xi}}$ & $\overline{\overline{\dot{I}}}$ & $\frac{m}{3}$ & $\frac{m}{ \pm}$ & $\stackrel{9}{\dot{\theta}}$ & & & 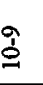 & $\bar{\infty}$ & $\hat{\infty}$ & $\hat{\infty}$ & $\infty$ & $\hat{\infty}$ & $\infty$ & $\infty$ & $\infty$ & $\infty$ & & $\infty$ \\
\hline 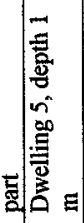 & 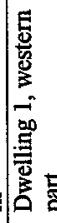 & 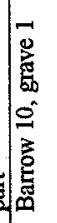 & 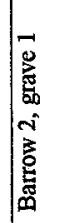 & 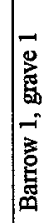 & 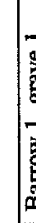 & 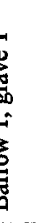 & 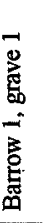 & 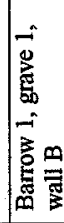 & 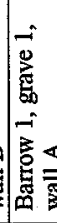 & $\overrightarrow{\overrightarrow{0}}$ & 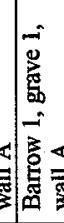 & 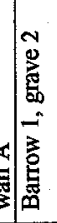 & 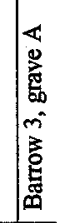 & 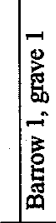 & 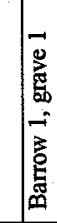 & 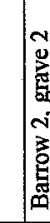 & & 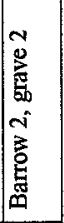 \\
\hline $\begin{array}{l}\text { zo } \\
0\end{array}$ & 范 & $\begin{array}{l}8 \\
0 \\
\end{array}$ & 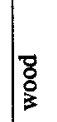 & 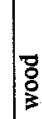 & 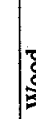 & 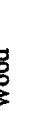 & छे & 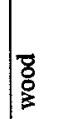 & $\begin{array}{l}8 \\
0 \\
0\end{array}$ & 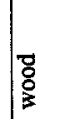 & 总 & 范 & 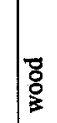 & 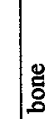 & 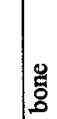 & $\frac{d}{m}$ & & 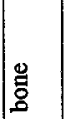 \\
\hline 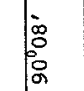 & $\begin{array}{l}\grave{a} \\
0 \\
0 \\
0 \\
0\end{array}$ & $\mid \begin{array}{c}\dot{2} \\
\bar{o} \\
\sigma\end{array}$ & 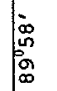 & $\begin{array}{l}i n \\
0 \\
0\end{array}$ & a & 3 & $\begin{array}{l}\text { in } \\
\text { in } \\
\text { the }\end{array}$ & $\begin{array}{l}\text { in } \\
\text { in } \\
\text { Os }\end{array}$ & $\begin{array}{l}\text { in } \\
\text { in } \\
\text { a } \\
\infty\end{array}$ & in & 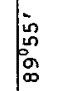 & 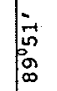 & $\begin{array}{l}\dot{\vdots} \\
\vdots \\
0\end{array}$ & $\begin{array}{l}\dot{0} \\
\vdots \\
0 \\
0\end{array}$ & $\begin{array}{l}\dot{0} \\
\text { : } \\
\text { : }\end{array}$ & $\begin{array}{l}\dot{े} \\
\vdots \\
\text { aे }\end{array}$ & & $\begin{array}{l}\dot{8} \\
\dot{0} \\
\text { o }\end{array}$ \\
\hline 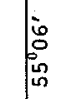 & 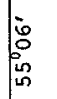 & 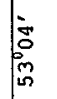 & $\begin{array}{l}\text { ì } \\
\vdots \\
0 \\
\text { in }\end{array}$ & 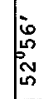 & $\begin{array}{l}5 \\
3 \\
3 \\
3 \\
3\end{array}$ & 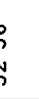 & $\begin{array}{l}\text { io } \\
\text { in } \\
\text { N. }\end{array}$ & 焉 & $\begin{array}{l}\text { i } \\
\text { in } \\
\text { in } \\
\text { in }\end{array}$ & 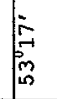 & 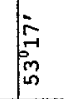 & 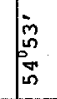 & $\begin{array}{l}\text { in } \\
\text { in } \\
0 \\
0\end{array}$ & 变 & 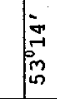 & & & 离 \\
\hline 瓷 & 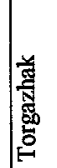 & 望 & 墨 & 5 & & 5 & $;$ & 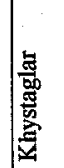 & 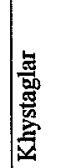 & 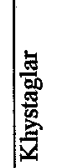 & 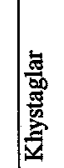 & 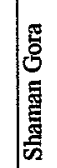 & 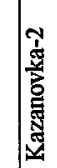 & 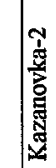 & 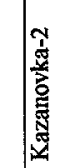 & & & 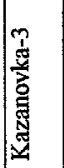 \\
\hline 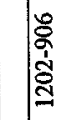 & 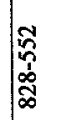 & $\stackrel{\stackrel{9}{2}}{\stackrel{2}{\grave{2}}}$ & 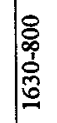 & 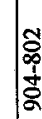 & & $\stackrel{8}{8}$ & 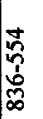 & 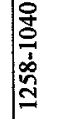 & 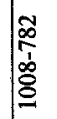 & 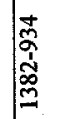 & 离 & 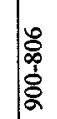 & 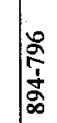 & 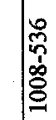 & 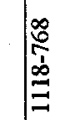 & 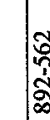 & 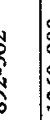 & 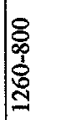 \\
\hline 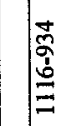 & 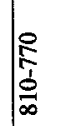 & 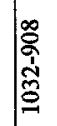 & 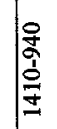 & 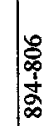 & & $\xi$ & 赵 & 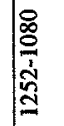 & 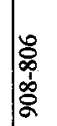 & 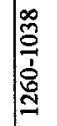 & 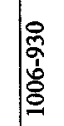 & 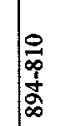 & 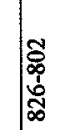 & 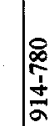 & 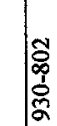 & 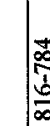 & $\begin{array}{l}0 \\
\vdots \\
\vdots \\
\vdots \\
0\end{array}$ & 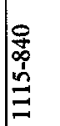 \\
\hline 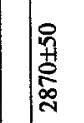 & 早 & 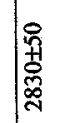 & 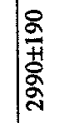 & श्र & & & 影 & 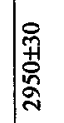 & 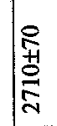 & 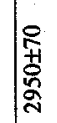 & 章 & 苳 & | & 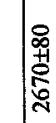 & 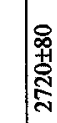 & & 早 & 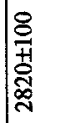 \\
\hline 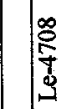 & 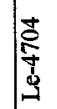 & 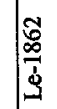 & 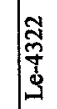 & 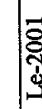 & & & 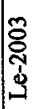 & 商 & 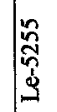 & | & 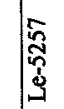 & $\begin{array}{l}\delta \\
\frac{\alpha}{\beta} \\
\dot{\Phi}\end{array}$ & 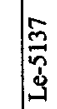 & 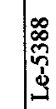 & 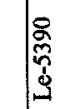 & $\overline{8}$ & 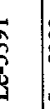 & 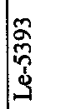 \\
\hline in & in & 0 & $\pi$ & $\infty$ & & & $\infty$ & $\approx$ & $\approx$ & $\cong$ & $\approx$ & $\cong$ & 12 & $\cong$ & $\cong$ & 5 & 4 & 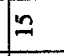 \\
\hline \pm & 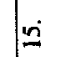 & 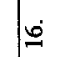 & $\Xi$ & 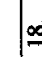 & & 2 & o & $\dot{\vec{n}}$ & ત્ & ஸे & İ & $\dot{s}$ & 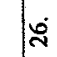 & $\dot{\Delta}$ & ه్ & g & 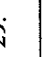 & |ळं \\
\hline
\end{tabular}




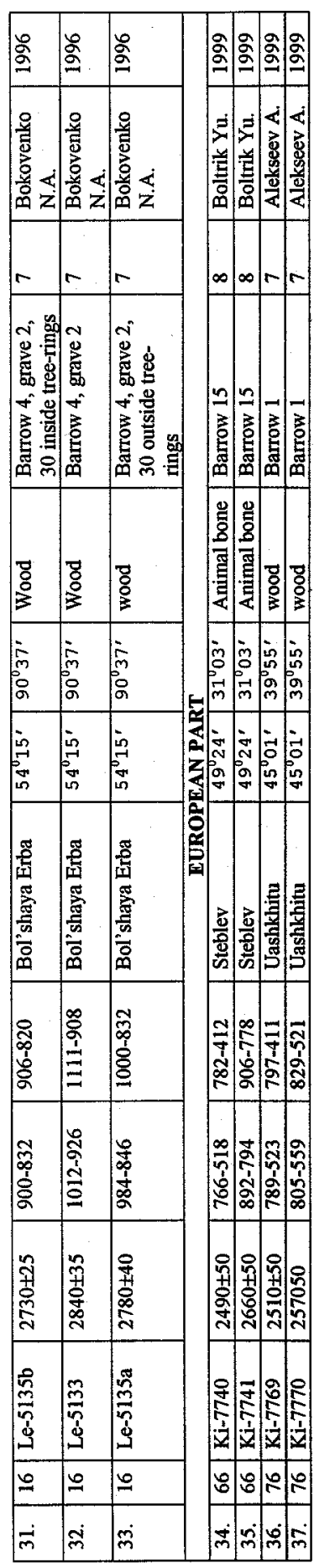




\section{Early Scythian Epoch (7th to 6th Centuries BC)}

\section{Archaeological Data}

This epoch in Central Asia is represented by the monuments of the so-called Aldy-bel' culture. On the basis of the peculiarities in the burial tradition and the typology of the artifacts (mirrors and horse bridles), this culture is dated to the 8th-6th centuries BC (Grach 1980; Savinov 1994). The oldest age (8th century BC) can only be linked to the Ust'-Khadynnyg barrow-1. The main period of existence of the Aldy-bel' culture monuments is determined to be the 7th-6th century BC (Chugunov 1999).

The key monuments of this period in Asia are the famous Bashadar and Tuekta barrows in the Sayan-Altai. There are two archaeological views on their chronology. According to the first, these barrows are dated to the 6th century BC (Marsadolov 1996). The second view is based on the chronology of the Pazyryk group barrows (discussed in the next section of this paper). In this case, the chronology of these barrows can be shifted to the 5th century $\mathrm{BC}$ if the interval between the construction of the Tuekta and the Pazyryk-2 barrows, determined as 128 years, is correct (Marsadolov 1996). The monuments of Eastern Kazakhstan, the Maiemir barrows, were dated to the 7th century BC (Marsadolov 1996). These barrows were included by some archaeologists in the so-called "Maiemir-Kelermess" phase of the development of Scythia-Siberian cultures (Gryaznov 1979).

The basis of the modern chronology of European Scythia is the dates of the separate royal barrows, which are the keystones for all European Scythian chronology. The most important for Ancient European Scythia is the royal Kelermess monuments located in the Northwestern Caucasus (Krasnodar district) and the Novozavedennoe barrows in the Stavropol district in the Pre-Caucasus region. Earlier, the age of these barrows was determined to lie on the boundary of the 7th-6th century BC. According to finds of near-eastern origin and the analyses of the military-political situation in Asia Minor, some researchers extended the time interval up to the middle of the 7th century BC (Alekseev 1992; Galanina 1997). Thus, there are two chronological systems for these barrows: a "long" and "short" one. Based on the long chronology, the Kelermess barrows were dated to 660-620 BC, based on the short one, they were dated to the end of the 7 th - the beginning of the 6th century BC. The Novozavedennoe barrows were dated to $650-590$ BC, which is similar to the Kelermess results.

\section{${ }^{14} \mathrm{C}$ Dating}

For the monuments related to this period, ${ }^{14} \mathrm{C}$ dates were first produced for the Sayan-Altai barrows of Southern Siberia, the most recent of which were previously unpublished. The first ${ }^{14} \mathrm{C}$ dates were obtained in 1999 for the different barrows and dated to the 2nd period in the Central Asia (Tuva Republic) monuments. The ${ }^{14} \mathrm{C}$ dates produced are presented in Table $2 .{ }^{14} \mathrm{C}$ dates for the Tuekta barrow were published earlier (Zaitseva et al. 1998) and are not presented here, although they are included in the graphical presentations. It should be noted that in spite of the large number of dates, the position of the Tuekta barrow on the calendar time scale was imprecisely determined due to the complicated character of the calibration curve. The ${ }^{14} \mathrm{C}$ dates for the Tuekta monument corresponded to two positions on the calibration curve: the 6th century BC and the 5th century BC. In the future, the position of the Tuekta barrow will be determined more precisely using "wiggle matching" together with dendro determinations.

The histogram of the distribution of the ${ }^{14} \mathrm{C}$ dates for the monuments belonging to the 2 nd period for both the Asian and European parts of Eurasian territories is shown in Figure 3. As one can see from the histogram, the monuments of the 2 nd period of the Scythian-type cultures for the Southern Sibe- 
ria and Central Asia regions have their oldest dates overlapping with those of the Sayan-Altai and European regions. According to the ${ }^{14} \mathrm{C}$ dates, the early Scythian monuments in Europe (the Kelermess and Novozavedennoe barrows) existed roughly (a little earlier) at the same time as the Tuekta and Bashadar barrows in the Sayan-Altai.

\section{Classical Scythian Epoch (5th to 4th Centuries BC)}

\section{Archaeological Data}

The key monuments of the classical Scythian period for the Asian territory are the famous Pazyryk group of barrows. Marasdolov $(1988,1996)$, based on a tree-ring chronology, suggested the following chronological succession for the Pazyryk barrows' construction: Pazyryk -2, -1, -4, -3, -5. According to the archaeological, tree-ring, and ${ }^{14} \mathrm{C}$ data he related the Pazyryk- 2 and 1 barrows to the middle of the 5th century BC: $455 \mathrm{BC}$ and $454 \mathrm{BC}$, respectively. The youngest barrow in this group is the Pazyryk-5 barrow which was dated to the end of the 5th century BC. There are some analogies in the artifacts and in the barrow construction between the Pazyryk group of barrows and the Seven Brothers group of barrows in Europe (the Kuban region) which are dated by Greek imported objects to the 5th century BC (Marsadolov 1987). Another point of view, based on the analyses of the imported objects, has also been expressed (NHA 1991), namely that the Pazyryk barrows date to the 4 th to the beginning of the 3rd century BC. Such dates have been accepted by some Russian archaeologists (Raev 1989; Chugunov 1993). Further research on the chronology of the Pazyryk barrows is presented in this issue (Bonani et al. 2001; McCormac et al. 2001; Vasiliev et al. 2001). There are over $30{ }^{14} \mathrm{C}$ determinations for these barrows, most of which have been published (Marsadolov 1984, 1987; Zaitseva et al. 1998).

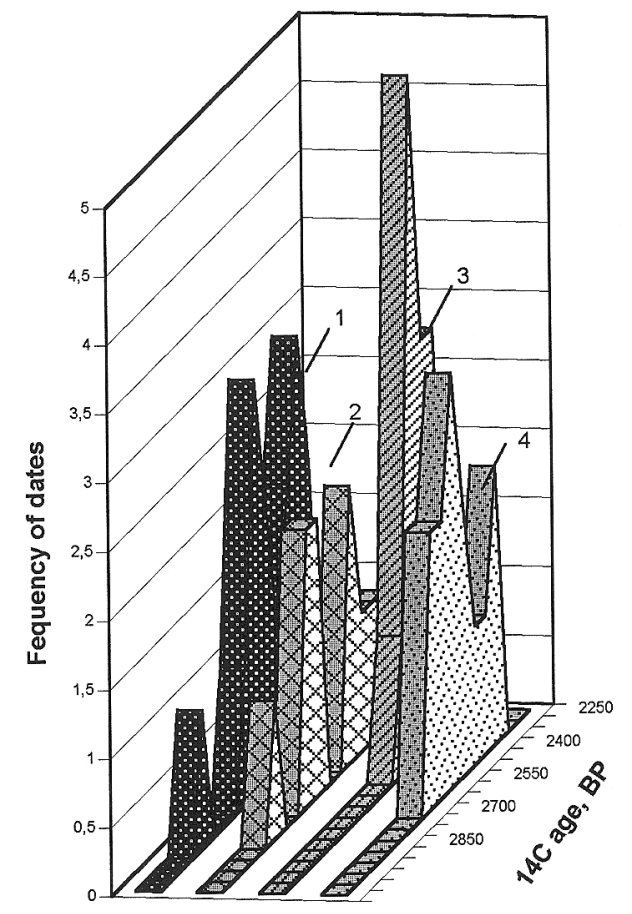

Figure 3 Histogram of the distribution of ${ }^{14} \mathrm{C}$ dates for the 2nd period of the Scythian epoch of different parts of Eurasia. $1=$ Southern Siberia, $2=$ Central Asia (Tuva), 3 = the Sayan-Altai, 4 = the European part. 


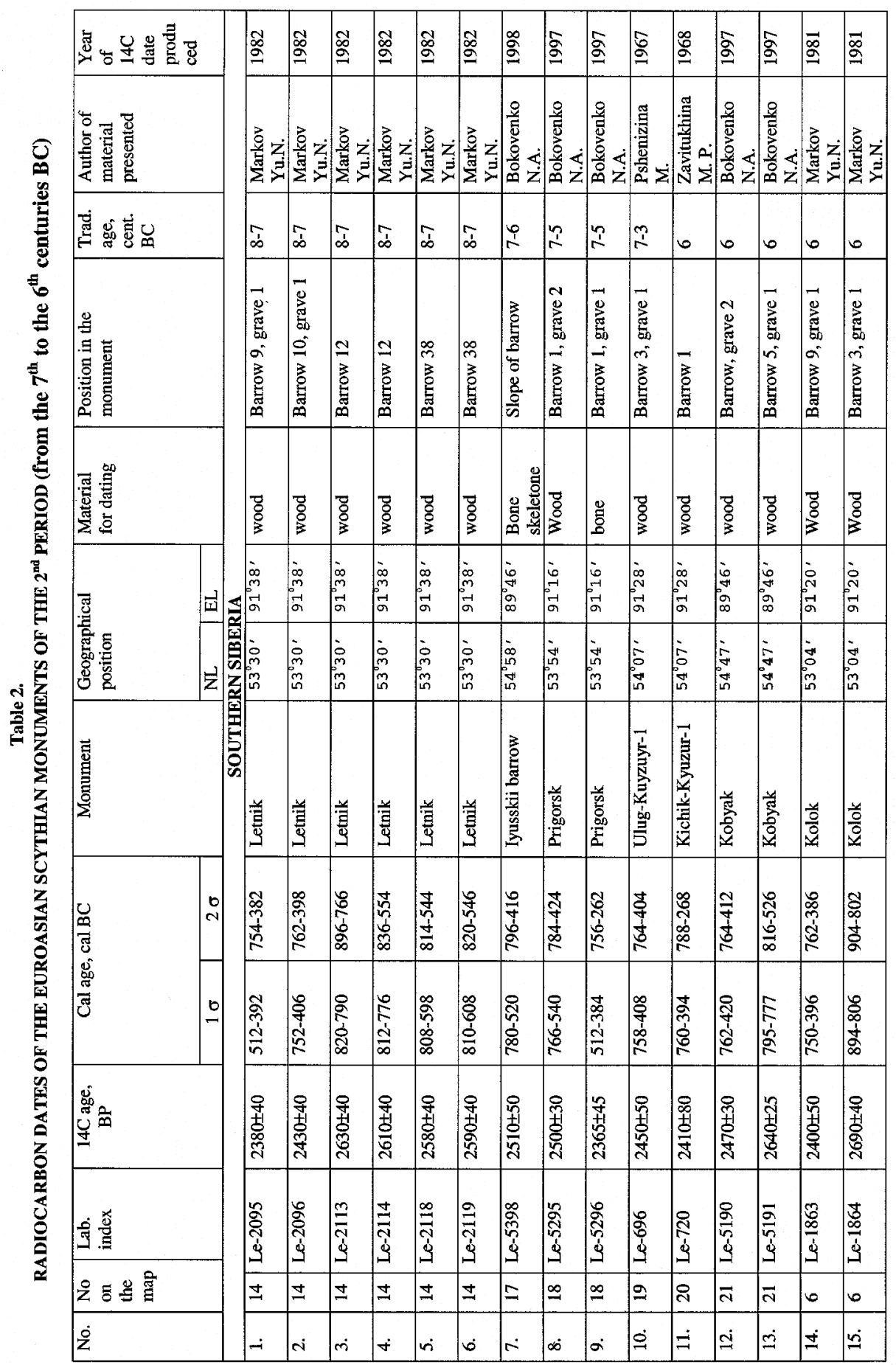




\begin{tabular}{|c|c|c|c|c|c|c|c|c|c|c|c|c|c|c|c|c|c|c|c|}
\hline 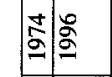 & ڤ్ & 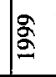 & ळ & 2 & ప̃ & & హ. & 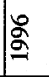 & ఏ్ & ڤે̆ & 余 & 翖 & 票 & Q & $\vec{\Xi}: \vec{\sigma}$ & 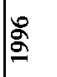 & 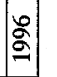 & 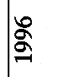 & 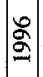 \\
\hline 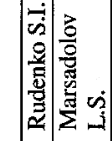 & 总 & خ & 悹 & 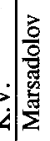 & 的 & & 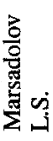 & 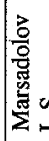 & 总 & 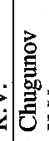 & 焉 & D & 俤 & 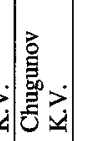 & 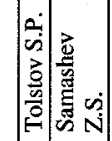 & & & & \\
\hline | & $\begin{array}{l}\infty \\
2 \\
\alpha\end{array}$ & $\infty$ & {$\left[\begin{array}{l}\alpha \\
\alpha \\
\alpha\end{array}\right.$} & s & b & & b & 13 & $b$ & b & 3 & 3 & $\widehat{6}$ & $\hat{b}$ & \begin{tabular}{|c|c|c|c|}
$\infty$ & \multicolumn{1}{c}{} \\
$\alpha$ & $\infty$
\end{tabular} & & & I & \\
\hline 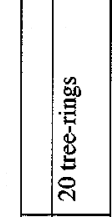 & 童 & 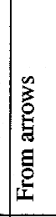 & & 容 & 굴 & & 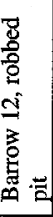 & $\frac{1}{2}$ & 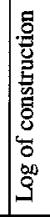 & 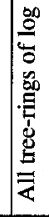 & 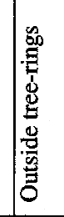 & 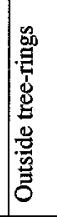 & 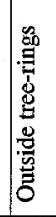 & 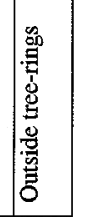 & 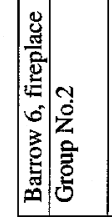 & $\bar{\Xi}$ & $\mid$ & 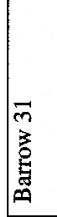 & $\mid$ \\
\hline \begin{tabular}{|l|l|} 
\\
\\
$\vdots$
\end{tabular} & 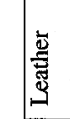 & 8 & 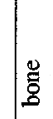 & $\overrightarrow{8}$ & $\overrightarrow{0}$ & & 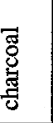 & $\mid \begin{array}{l}\overrightarrow{0} \\
3\end{array}$ & 8 & 范 & $\begin{array}{l}8 \\
8 \\
8 \\
3\end{array}$ & 要 & 送 & 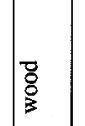 & 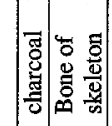 & & 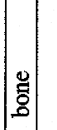 & $\mid$ & 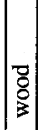 \\
\hline 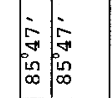 & 官 & $\begin{array}{l}\dot{i} \\
m \\
m \\
m \\
m\end{array}$ & 离 & 寅 & 砶 & & ì & 仿 & 空 & in & 离 & in & 施 & $m$ & 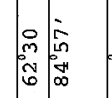 & 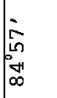 & & $\begin{array}{l}\dot{0} \\
\dot{0} \\
0 \\
0 \\
0\end{array}$ & \\
\hline 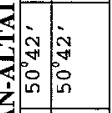 & 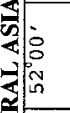 & $\begin{array}{l} \\
\dot{0} \\
i \\
\tilde{N} \\
0\end{array}$ & $\mid \begin{array}{l}\dot{y} \\
0 \\
0 \\
n \\
n\end{array}$ & 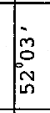 & 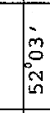 & & ì & \begin{tabular}{|l}
$n$ \\
0 \\
0 \\
$n$ \\
$n$ \\
$n$
\end{tabular} & 豙 & 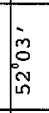 & 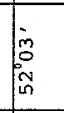 & 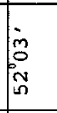 & 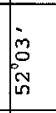 & 冓 & 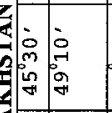 & 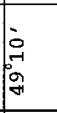 & & 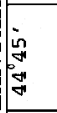 & 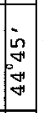 \\
\hline 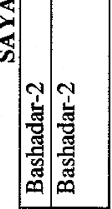 & 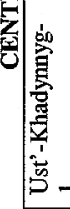 & 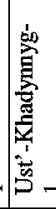 & 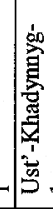 & 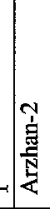 & 咅 & & 竎 & 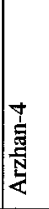 & 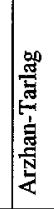 & 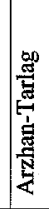 & 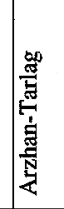 & 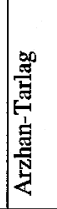 & 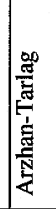 & 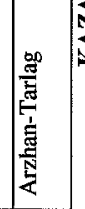 & 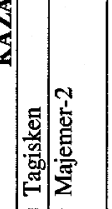 & & $\mid$ & 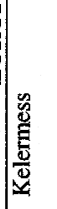 & 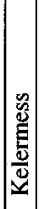 \\
\hline 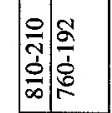 & 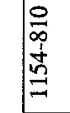 & $\mid$ & $\begin{array}{l}\infty \\
\frac{\infty}{1} \\
\frac{1}{\infty} \\
m\end{array}$ & 啥 & . & & 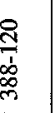 & 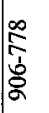 & 票 & ס & 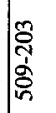 & 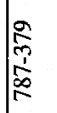 & 䧻 & 绾 & 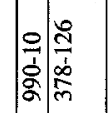 & & $\mid$ & 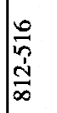 & $\mid$ \\
\hline 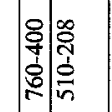 & 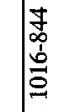 & 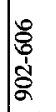 & $\frac{1}{0}$ & 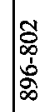 & 蛋 & & ‡ั & 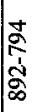 & 先 & 常 & 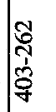 & 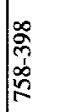 & 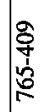 & శ్ & 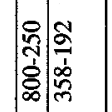 & & $\mid$ & 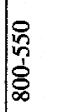 & $\mid$ \\
\hline 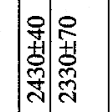 & 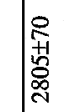 & 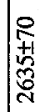 & 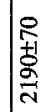 & 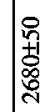 & 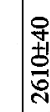 & & 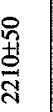 & $\emptyset$ & 章 & $\mid \begin{array}{l}n \\
y \\
1 \\
\vdots \\
y \\
y\end{array}$ & \begin{tabular}{|l}
8 \\
i \\
$\frac{1}{2}$ \\
in
\end{tabular} & 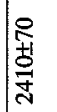 & 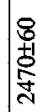 & 它 & 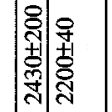 & 总 & 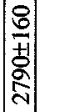 & 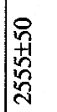 & $\mid$ \\
\hline 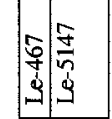 & 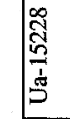 & 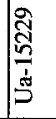 & 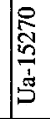 & 告 & $\begin{array}{l}8 \\
8 \\
\\
3\end{array}$ & & 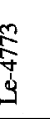 & $\frac{8}{8}$ & 点 & 密 & 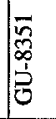 & 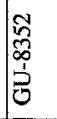 & $\begin{array}{l}0 \\
0 \\
0 \\
0 \\
0 \\
0 \\
0 \\
0\end{array}$ & 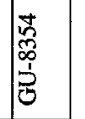 & 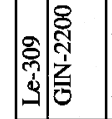 & & 预 & 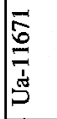 & $\mid$ \\
\hline$\infty$ & 8 & 18 & if & in & คิ & & in & in & $\bar{n}$ & $\bar{n}$ & in & $\bar{n}$ & $\bar{n}$ & $\bar{n}$ & nn & $\infty$ & $\infty$ & 8 & 8 \\
\hline 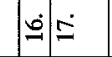 & $\stackrel{\infty}{\infty}$ & 2 & ते & $\dot{\pi}$ & तi & & त் & सं & inj & i் & $\dot{\pi}$ & జి & तें & m. & $\dot{m} \mid \vec{m}$ & $m$ & $\dot{m}$ & $\ddot{m}$ & "ें \\
\hline
\end{tabular}




\begin{tabular}{|c|c|c|c|c|c|c|c|c|c|c|c|c|}
\hline ฏ̊ & $\approx$ & 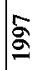 & & & $\overline{2}$ & హి & ळ & & 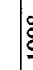 & & $\approx$ & \\
\hline & 离 & छ & & & & & & & & & & \\
\hline r & r & I & & & r & 10 & i & $\stackrel{1}{I}$ & & & $\stackrel{0}{i}$ & \\
\hline 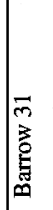 & \begin{tabular}{|}
$\bar{m}$ \\
$\hat{z}$ \\
$\bar{E}$ \\
m.
\end{tabular} & लि & & & 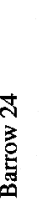 & 䇉 & $\frac{1}{2}$ & $\frac{\pi}{3}$ & & 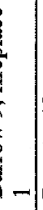 & 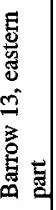 & \\
\hline 宮 & 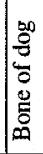 & 送 & & & $\begin{array}{l}8 z \\
\\
\end{array}$ & $\stackrel{\dddot{\Xi}}{8}$ & 兽 & 8 & & & 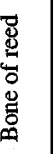 & \\
\hline $\begin{array}{l}0 \\
\dot{\alpha} \\
0 \\
0 \\
0\end{array}$ & 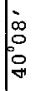 & $\begin{array}{l}\infty \\
0 \\
0 \\
0 \\
0\end{array}$ & & & 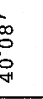 & $\begin{array}{l}\infty \\
\infty \\
m \\
m \\
m\end{array}$ & $\mid \begin{array}{c}\infty \\
m \\
m \\
m\end{array}$ & & & 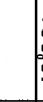 & 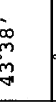 & 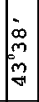 \\
\hline $\begin{array}{c}\text { sat } \\
\text { sits }\end{array}$ & 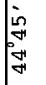 & 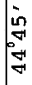 & & & in & 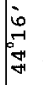 & $\underset{4}{2}$ & & & 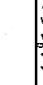 & : & \\
\hline 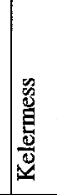 & 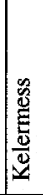 & 婴 & & & 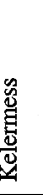 & 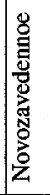 & & & & 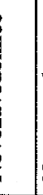 & 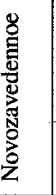 & \\
\hline 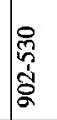 & 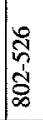 & $\vec{y}$ & & & 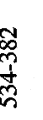 & 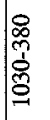 & & & & 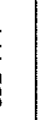 & 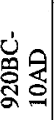 & 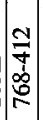 \\
\hline 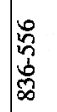 & 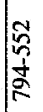 & ? & & & 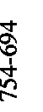 & 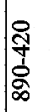 & & & & 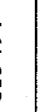 & 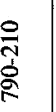 & 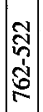 \\
\hline 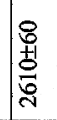 & $\begin{array}{l}\text { 㝵 } \\
\text { 夏 }\end{array}$ & $\bar{t}$ & & & 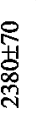 & 导 & & & & 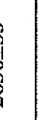 & 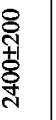 & 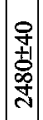 \\
\hline$\frac{\infty}{\frac{\infty}{3}}$ & 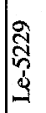 & $\bar{N}$ & & & $\begin{array}{l}\text { 雨 } \\
\vdots \\
\vdots\end{array}$ & 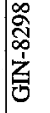 & & & & 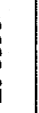 & 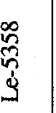 & 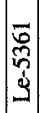 \\
\hline 8 & 8 & 8 & & & 8 & $\overline{\boldsymbol{\sigma}}$ & $\sqrt{7}$ & 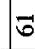 & & 5 & $\bar{\sigma}$ & 15 \\
\hline$\dot{m}$ & 㐫 & & & & $\dot{\vec{q}}$ & j & & $1+$ & & & نه & \\
\hline
\end{tabular}


The middle stage of the Scythian epoch is reflected in Central Asia by the Dogee-Baary-2 barrows in the Tuva Republic. These monuments have been under investigation for more than 10 years and the materials found relating to the burial tradition and the culture of the early nomads in this region have been dated to the 6th to the 4 th century BC (Chugunov 1994, 1996). The majority of ${ }^{14} \mathrm{C}$ dates produced for this monument have been published (Sementsov et al. 1998), here, we present the ${ }^{14} \mathrm{C}$ dates produced in 1998-1999.

For the forest-steppe zone of the Black Sea region, the Steblev monuments play an important role in the chronology of Classical Scythia, some barrows of which are dated to the 5th-4th century BC (Skorii 1997). The most interesting among them is barrow $\mathrm{Nr} 3$, which contained Greek amphora dated to 440 BC (Monakhov 1999).

The key monuments of Classical Scythia in the European part of Eurasia are the Seven Brothers, Solokha, Chertomlyk, Oguz, and Aleksandropol royal barrows of the Pontic region. According to typological analyses, the oldest among them are the Seven Brothers and Solokha barrows and the youngest is the Aleksandropol barrow. The chronological position of the Chertomlyk and the Oguz barrows lies between these.

The Seven Brothers barrows are located in the Taman Peninsula on the left bank of the Kuban River in the Krasnodar district. This monument consists of a group of barrows belonging to different chronological periods. Thus, barrow Nr 4 belongs to the so-called "older group" (460-425 BC) compared with barrows $\mathrm{Nr} 6$ (400-380 BC) and Nr 7 ("younger group").

Four famous Scythian royal barrows are located along a single line $126 \mathrm{~km}$ from the Oguz barrow in the south to the Aleksandropol barrow in the north. From the available evidence, the royal tombs have been placed along the main transport route, in the center of which is situated the Solokha barrow, which is the oldest one (Yu V Boltrik, personal communication 1999).

According to archaeological evidence, the Solokha barrow is dated to 420/410-375 BC (Alekseev 1992). The chronological interval (based on silver ware, smart objects, harness) for the Chertomlyk barrow is from the 5th to the second half of the 4th century BC. The amphorae's brands also give a wide age range. The more reliable dates are $350-325 \mathrm{BC}$. There is some controversy concerning the date of the construction of this barrow, connected to its use as either:

1. The burial of the well-known Scythian king Ateas who died in 339 BC (thus timing this barrow construction to 339 BC) (Boltrik and Fialko 1995), or

2. The burial of the "Anonymous" king who died in the winter of 328/329 BC (Alekseev 1996).

According to the archaeological artifacts, the Oguz barrow can be dated to 350-300 BC, or 350-325 $\mathrm{BC}$, and the Aleksandropol barrow to 330-300 BC.

\section{${ }^{14}$ C Dating}

The ${ }^{14} \mathrm{C}$ dates of the monuments belonging to the 3rd period of the Scythian epoch are presented in Table 3. The majority of dates for these were produced in 1996-99, particularly for the European Scythian monuments. Some of the dates for the ordinary monuments in Southern Siberia produced earlier but not previously published are presented here. Both earlier and new ${ }^{14} \mathrm{C}$ dates for the Pazyryk group (in Sayan-Altai), the Dogee-Barry-2 and the Kopto barrows (in Central Asia, Tuva Republic) based on tree rings were published earlier (Zaitseva et al. 1998; Sementsov et al. 1998), the newer dates will be used for the more precise determination of the calendar position of these barrows and will be presented and discussed in separate reports in this issue (Bonani et al. 2001; McCormac et al. 2001; Vasiliev et al. 2001). 


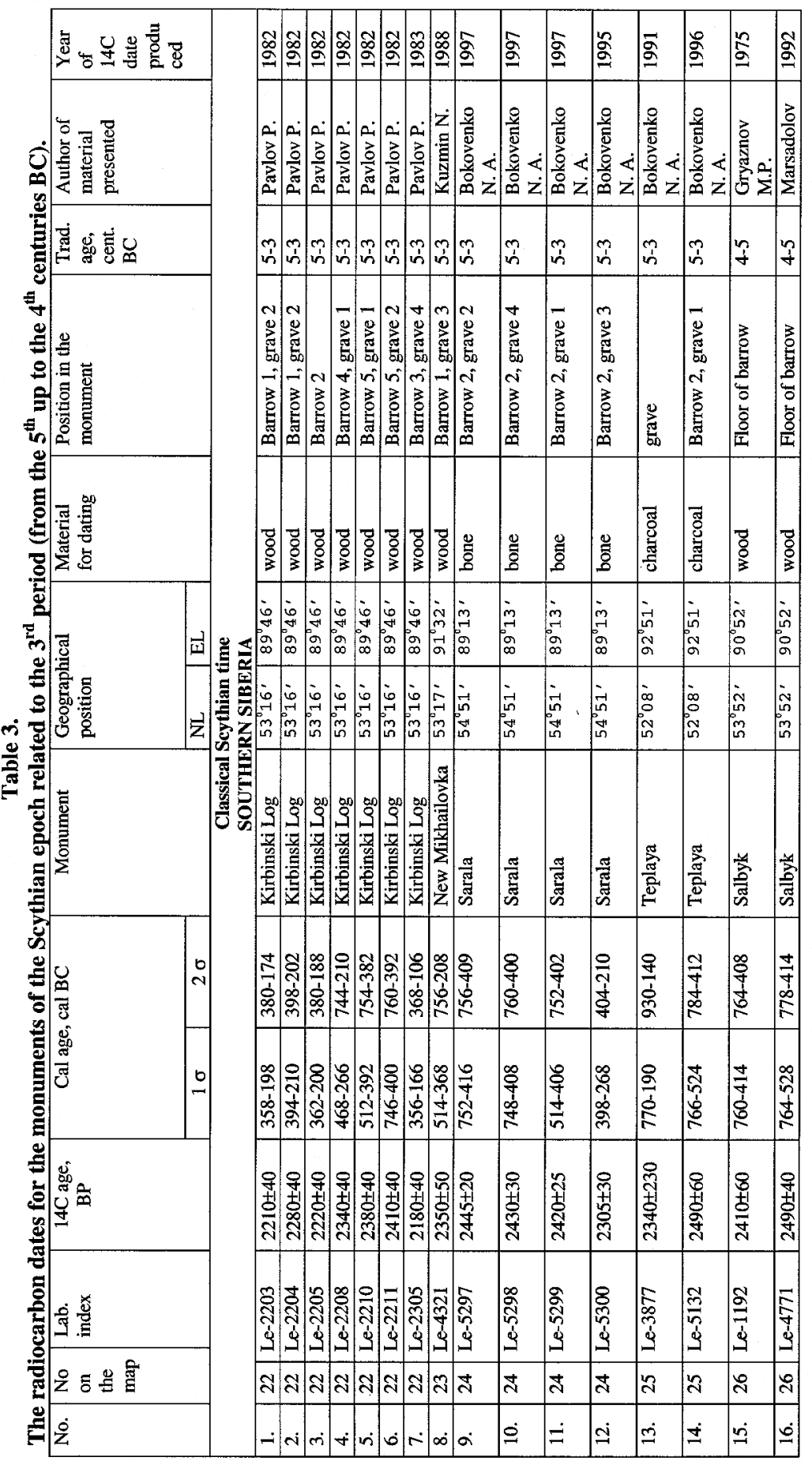




\begin{tabular}{|c|c|c|c|c|c|c|c|c|c|c|c|c|c|c|c|c|c|c|c|}
\hline$\stackrel{2}{2}$ & 命 & 苂 & & & 2 & & & & & $\cong$ & 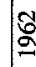 & & & $\stackrel{2}{2}$ & 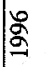 & $\stackrel{2}{2}$ & $\stackrel{\circ}{\circ}$ & 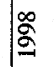 & 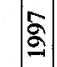 \\
\hline 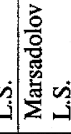 & | & 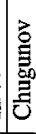 & & & 总 & & & & & 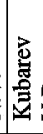 & & & & 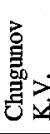 & 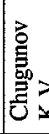 & 总 & 总 & & \\
\hline q & in & in & & r & 3 & $\frac{w}{4}$ & & $f$ & f & t & $\nabla$ & 4 & f & ț & d & İ & $\begin{array}{l}7 \\
0\end{array}$ & ț & t \\
\hline 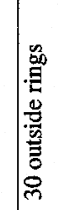 & 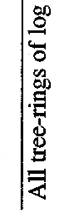 & 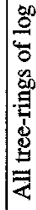 & & : & 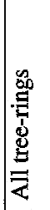 & 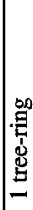 & & 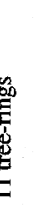 & 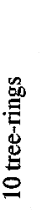 & 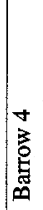 & $\begin{array}{l}0 \\
0 \\
0 \\
0 \\
0\end{array}$ & $\tilde{\overbrace{}}$ & 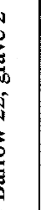 & 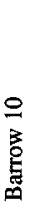 & 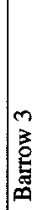 & $\overrightarrow{\mid \vec{z}}$ & 足 & 吕 & | \\
\hline$\overline{8}$ & 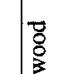 & $\overline{8}$ & & 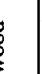 & $\begin{array}{l}\overrightarrow{0} \\
0\end{array}$ & 总 & & 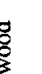 & 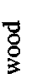 & 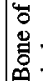 & "ृ & & & 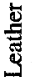 & 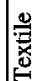 & 总 & 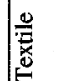 & 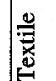 & \begin{tabular}{|l} 
zo \\
है
\end{tabular} \\
\hline $\begin{array}{l}\hat{i} \\
\text { in } \\
\text { on } \\
\alpha\end{array}$ & $\begin{array}{l}\vec{i} \\
\vec{n} \\
\hat{\infty}\end{array}$ & $\begin{array}{l}\vec{b} \\
\text { 命 } \\
\text { 命 }\end{array}$ & & & 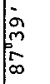 & $\mathrm{m}$ & & & 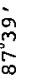 & 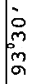 & 亥 & $1 \%$ & & 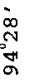 & 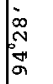 & 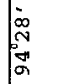 & 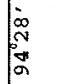 & 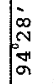 & $\mid \dot{\sigma}$ \\
\hline 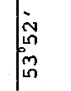 & 列| & $\begin{array}{l}\dot{a} \\
\text { aे } \\
0 \\
0 \\
0\end{array}$ & & & $\begin{array}{l}\dot{0} \\
\vdots \\
\vdots \\
\sigma_{2}\end{array}$ & 5 & & 4 & 商 & 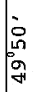 & $\vec{g}$ & is & & 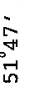 & $\begin{array}{l}\text { in } \\
\text { in } \\
\text { in }\end{array}$ & 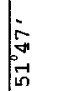 & $\begin{array}{l}\text { is } \\
\text { in }\end{array}$ & $\begin{array}{l}\bar{i} \\
\bar{c} \\
\vec{c}\end{array}$ & in \\
\hline 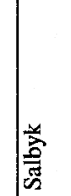 & 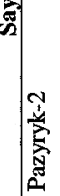 & 養 & & 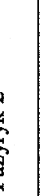 & 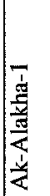 & 点 & & 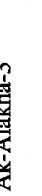 & 递 & 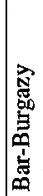 & 总 &. & & 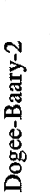 & 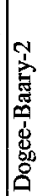 & 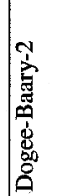 & 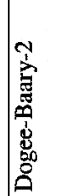 & 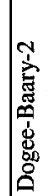 & 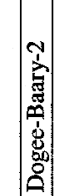 \\
\hline 总 & 齐 & ชู & & 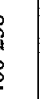 & 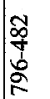 & 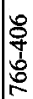 & & d. & 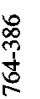 & 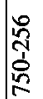 & $\stackrel{N}{N}$ & 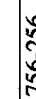 & & 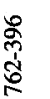 & 童 & 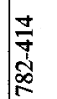 & 总 & 喜 & $\begin{array}{l}\vec{f} \\
: \\
:\end{array}$ \\
\hline$\frac{0}{7}$ & $\mid \begin{array}{l}\infty \\
\infty \\
0 \\
\infty \\
\vdots \\
\sigma\end{array}$ & g్ & & 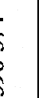 & 敢 & $\frac{\pi}{5}$ & & 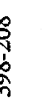 & 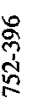 & $\mid$ & 8 & $\mid$ & & 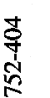 & $\frac{8}{9}$ & 䞒 & 芯 & 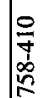 & 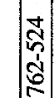 \\
\hline 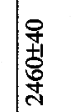 & 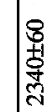 & 5 & & S & 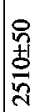 & \pm & & 羃 & $\begin{array}{l}8 \\
+10\end{array}$ & 景 & $\frac{\rho}{t}$ & & & $\begin{array}{l}\text { 早 } \\
\text { 岁 } \\
\text { d }\end{array}$ & 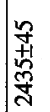 & $\mid \begin{array}{l}\text { 栗 } \\
\text { 恶 }\end{array}$ & 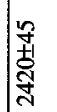 & 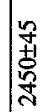 & $\mid$ \\
\hline $\mid \begin{array}{c}3 \\
\vdots \\
\frac{3}{2}\end{array}$ & 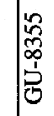 & $\tilde{n}$ & & 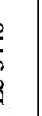 & 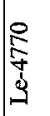 & 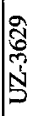 & & S. & & 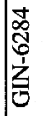 & 6 & 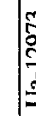 & & 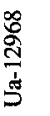 & 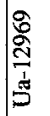 & 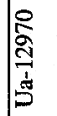 & 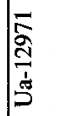 & 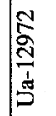 & 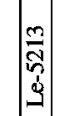 \\
\hline 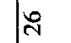 & $\mathrm{m}$ & $m$ & & 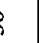 & $F$ & 18 & & $\overrightarrow{7}$ & $\forall$ & F & + & 8 & & in & n & $\approx$ & $\operatorname{lin}$ & in & \\
\hline$\therefore$ & $\infty$ & & & & $\dot{\sim}$ & & & & $1 \pm$ & & & & & $\infty$ & & ஓं & $\dot{\square}$ & ه' & \\
\hline
\end{tabular}




\begin{tabular}{|c|c|c|c|c|c|c|c|c|c|c|c|c|c|c|c|c|c|c|c|}
\hline 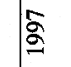 & ळे & 2 & 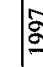 & & 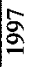 & 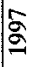 & 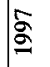 & 2 & & & 尊 & $\stackrel{2}{2}$ & $\stackrel{2}{2}$ & 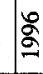 & ‡ & & 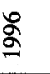 & \& & ఏ \\
\hline 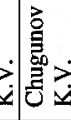 & 总 & : & & & 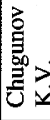 & 总 & : & 总 & & & & $\mid \begin{array}{l}3 \\
0 \\
0 \\
\frac{2}{2} \\
\frac{2}{4}\end{array}$ & 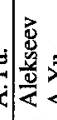 & & & & & & 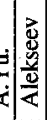 \\
\hline Jे & J & $b$ & 3 & & 3 & 3 & 3 & 18 & . & t & o & in & in & $n$ & in & & $n$ & in & + \\
\hline 垈 & 量 & 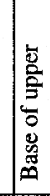 & & & 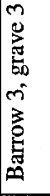 & 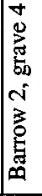 & 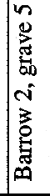 & 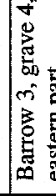 & & & & 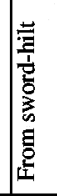 & 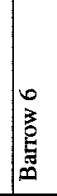 & 资 & & & t. & 瓷 & 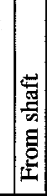 \\
\hline $\begin{array}{l}\overline{8} \\
\bar{\beta} \\
\xi\end{array}$ & 容 & 总 & 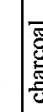 & & $\begin{array}{l}\overrightarrow{0} \\
\bar{\beta}\end{array}$ & 恖 & $\begin{array}{l}\bar{Z} \\
0 \\
3\end{array}$ & 8 & 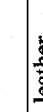 & & 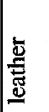 & 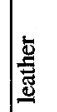 & 辰 & 刍 & 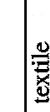 & & $\overline{8}$ & $\overline{\bar{\delta}}$ & $\left|\begin{array}{|l}\vec{b} \\
3 \\
3\end{array}\right|$ \\
\hline 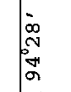 & 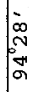 & 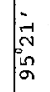 & ì & & $\begin{array}{l}\vec{i} \\
\vec{N} \\
\vec{n}\end{array}$ & 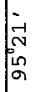 & 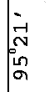 & 离 & 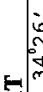 & & 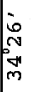 & 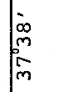 & 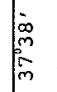 & 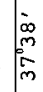 & 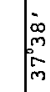 & & & 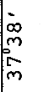 & \\
\hline 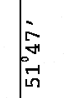 & $\begin{array}{l}\text { in } \\
\text { in } \\
\text { in }\end{array}$ & 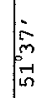 & 离 & & 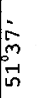 & 离 & $\begin{array}{l}\dot{1} \\
m \\
m \\
c\end{array}$ & $\begin{array}{l}\hat{i} \\
\text { man } \\
\overrightarrow{i n}\end{array}$ & 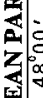 & & $\dot{0}$ & 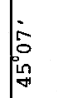 & $\begin{array}{l}\hat{i} \\
\text { in } \\
\text { in }\end{array}$ & $\begin{array}{l}i \\
i \\
\text { in } \\
\text { in }\end{array}$ & ì & & $\begin{array}{l}\dot{\delta} \\
\text { in } \\
\text { in }\end{array}$ & $\begin{array}{l}i \\
\text { in } \\
\text { in }\end{array}$ & i \\
\hline 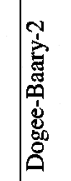 & 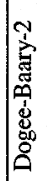 & 莺 & 窇 & & 产 & 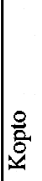 & 产 & 产 & 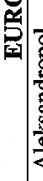 & & 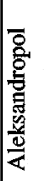 & 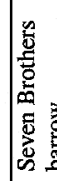 & 站 & 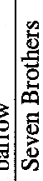 & 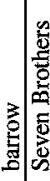 & 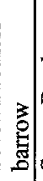 & & & 章 \\
\hline 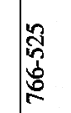 & 芯 & 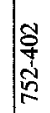 & 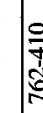 & & 离 & 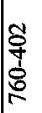 & $\frac{1}{7}$ & 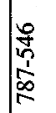 & $y$ & & & : & $\frac{\pi}{b}$ & $\%$ & 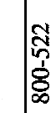 & & 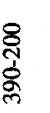 & & 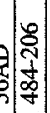 \\
\hline 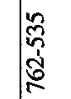 & 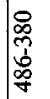 & 过 & 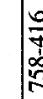 & & 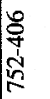 & 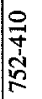 & 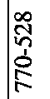 & ?ొ & & & & 硗 & 究 & خั้ & 恶 & & ָั ָે & & |ct \\
\hline 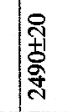 & 密 & 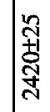 & 帒 & & 恶 & 兽 & $\begin{array}{l}8 \\
\text { 竞 }\end{array}$ & $\mp$ & & & 章 & 亳 & 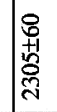 & P & 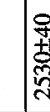 & & 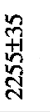 & 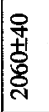 & 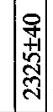 \\
\hline 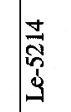 & 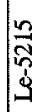 & 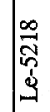 & 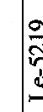 & & $\begin{array}{l}\bar{N} \\
\vdots \\
\vdots \\
\vdots\end{array}$ & స్ָ & 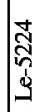 & స్ָુ & & & 於 & 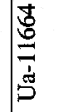 & 范 & 象 & 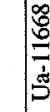 & 3 & है & 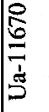 & \\
\hline in & in & in & in & & in & in & $n$ & in & & & ह & $\delta$ & $\widehat{\sigma}$ & $\delta$ & 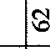 & & ชర & శ్ & 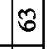 \\
\hline$\stackrel{\dot{m}}{m}$ & min & 'ं & $\Leftrightarrow$ & & $\stackrel{\infty}{m}$ & 18 & & & & & & 过 & ஆ & 16 & 10 & & 我 & के & ஜ் \\
\hline
\end{tabular}




\begin{tabular}{|c|c|c|c|c|c|c|c|c|c|c|c|c|c|c|c|}
\hline & g̊ & & 渠 & 。 & & 羉 & 息送 & & 弯 & 曽 & $\bar{\sigma}$ & 串 & & & 离 \\
\hline & & & & & 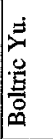 & & & & & & & & & & \\
\hline+ & + & 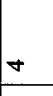 & + & d & + & + & $\rightarrow+$ & + & + & + & + & + & \pm & + & \\
\hline 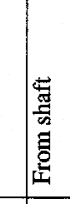 & 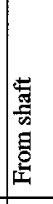 & & 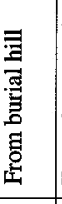 & & 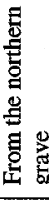 & & & & 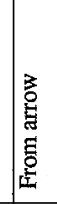 & 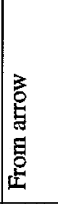 & & & & & \\
\hline 荘 & 营 & 总 & 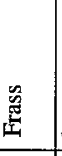 & 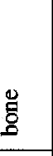 & & \begin{tabular}{|l} 
总 \\
$口$
\end{tabular} & 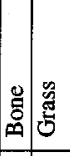 & & 8 & 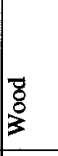 & & 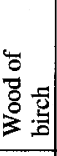 & 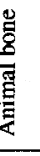 & & 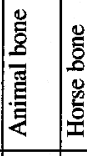 \\
\hline 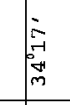 & $\begin{array}{l}\hat{y} \\
\text { 恶 }\end{array}$ & & 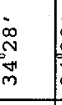 & w & 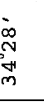 & & & 年 & 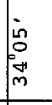 & 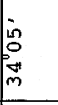 & & 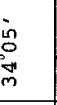 & 离 & 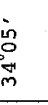 & \\
\hline 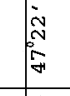 & $\mid \begin{array}{l}\tilde{y} \\
\tilde{y} \\
\vdots \\
\end{array}$ & & ") & , & لَّ & & 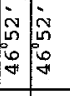 & 悉 & 离 & 票 & 拳 & 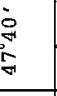 & & $\therefore$ & 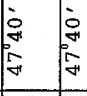 \\
\hline $\mid$ & $\mid$ & & 言 & 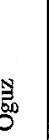 & 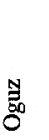 & 罗 & 站 & $\Phi$ & 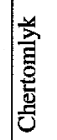 & & 产 & & & 产 & \\
\hline 席 & 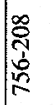 & 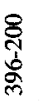 & 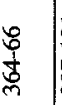 & $\overline{\frac{\pi}{1}}$ & ִָ & & 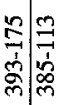 & & 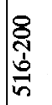 & 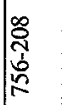 & ఫ్ & 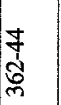 & & 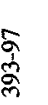 & 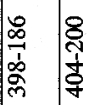 \\
\hline 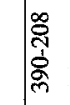 & 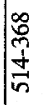 & 离 & 苛 & 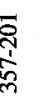 & $\bar{i}$ & & 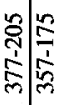 & & & 象 & 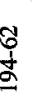 & 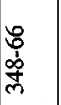 & 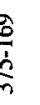 & $\frac{5}{\alpha}$ & \\
\hline 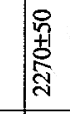 & 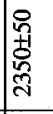 & 衰 & 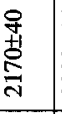 & 密 & 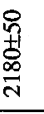 & & 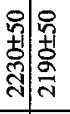 & & 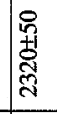 & 密 & 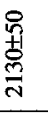 & 蜜 & 略 & 害 & \\
\hline 요영 & & & & & $\searrow$ & & 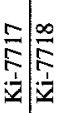 & & & & 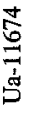 & & & त्ञ & 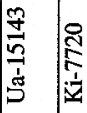 \\
\hline 8 & 8 & 8 & 8 & 8 & उ & E & t & $\because$ & 3 & 3 & & 8 & 8 & 8 & 3 \\
\hline$\dot{n}$ & مَં & & $\dot{t}$ & $\dot{n}$ & ڤ் & $\dot{n}$ & $i^{\circ} \mid 0^{\circ}$ & 8 & $\vec{b}$ & is & '. & $\dot{f}$ & $\dot{6}$ & : & $\ddot{0}$ \\
\hline
\end{tabular}




\begin{tabular}{|c|c|c|c|c|c|c|c|c|c|c|c|c|c|c|c|c|c|}
\hline హ్ & 㻌 & बे & बू & 总 & बे & 要 & $\begin{array}{c}g \\
g\end{array}$ & $\stackrel{g}{\Omega}$ & & 2 & $\begin{array}{l}\infty \\
\vdots \\
0\end{array}$ & : & 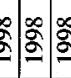 & & \& & & \\
\hline 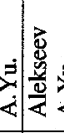 & & $=$ & & 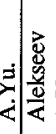 & & 党 & 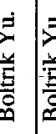 & 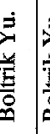 & & 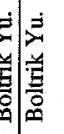 & 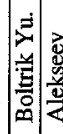 & 惫 & 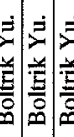 & & 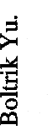 & 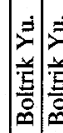 & 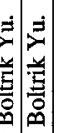 \\
\hline+ & + & + & $\forall$ & + & + & & + & + & & $+t$ & 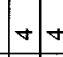 & & $\theta+4$ & & \pm & & +8 \\
\hline & & 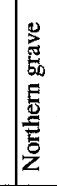 & 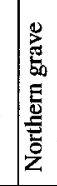 & & 爮 & 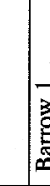 & & 鹿 & & 童 & 辛 & & 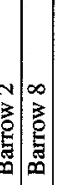 & & & & 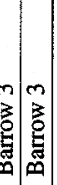 \\
\hline 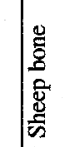 & 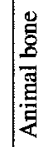 & 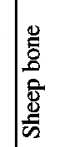 & 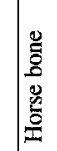 & $\overline{8}$ & 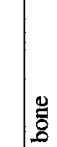 & 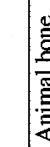 & $\frac{0}{8}$ & 兽 & & 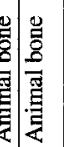 & 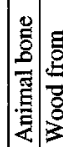 & & 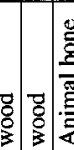 & & 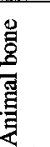 & & 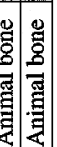 \\
\hline $\begin{array}{l}\text { in } \\
0 \\
\text { on } \\
\text { in }\end{array}$ & $\begin{array}{l}\text { in } \\
0 \\
\text { en }\end{array}$ & 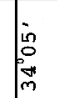 & 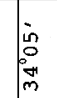 & 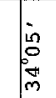 & 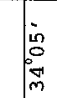 & 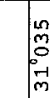 & 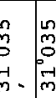 & 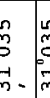 & & 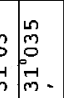 & 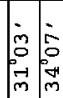 & & 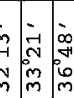 & & 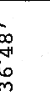 & & $\begin{array}{l}n \\
n \\
m\end{array}$ \\
\hline 严 & 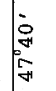 & $\mid \begin{array}{l}\dot{0} \\
\vdots \\
\vdots \\
\vdots\end{array}$ & 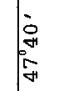 & 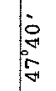 & $\mid$ & لנ & 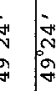 & 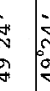 & & 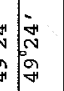 & 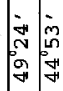 & & 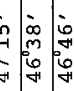 & & 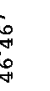 & & \\
\hline 离 & 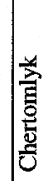 & 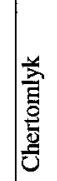 & 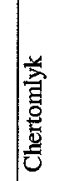 & 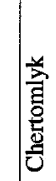 & | & 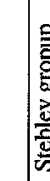 & 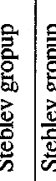 & 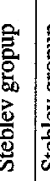 & & $\begin{array}{l}: \\
:\end{array}$ & 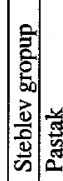 & & 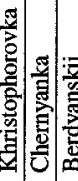 & & & & 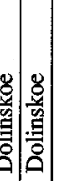 \\
\hline $\mid \begin{array}{l}\infty \\
\infty \\
\infty \\
\infty \\
\infty\end{array}$ & 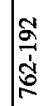 & 或 & & 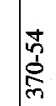 & $\frac{\frac{2}{1}}{\frac{1}{i n}}$ & $\frac{8}{\square}$ & 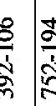 & ¿ & & 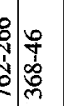 & 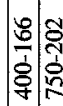 & & 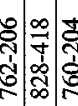 & & 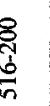 & & 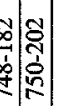 \\
\hline$\frac{\infty}{\frac{2}{3}}$ & 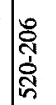 & 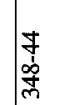 & 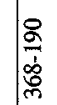 & 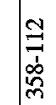 & 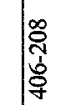 & $\frac{\delta}{d}$ & 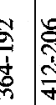 & 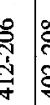 & & 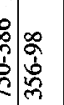 & 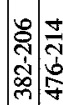 & & 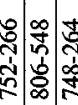 & & 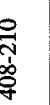 & & 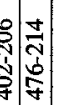 \\
\hline 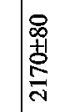 & 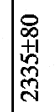 & 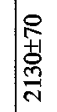 & |ृ & $\begin{array}{l}\frac{8}{0} \\
\frac{1}{1} \\
\frac{1}{4}\end{array}$ & 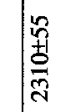 & $\begin{array}{l}8 \\
\frac{8}{5} \\
\delta\end{array}$ & 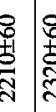 & 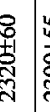 & & 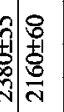 & 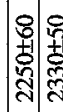 & & 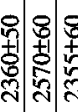 & & 8 & 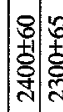 & \\
\hline 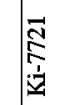 & 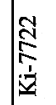 & 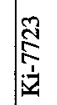 & 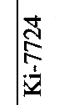 & 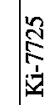 & 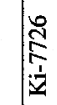 & $\frac{\pi}{3}$ & $\frac{2}{\frac{c}{2}}$ & $\frac{n}{2}$ & & 恼 & 商 & & \begin{tabular}{c}
\multirow{2}{*}{$\frac{\pi}{2}$} \\
$\frac{1}{2}$
\end{tabular} & 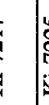 & 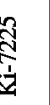 & & 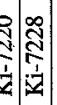 \\
\hline 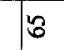 & 8 & 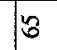 & 18 & 16 & 16 & 8 & 88 & 8 & 8 & 88 & $: 8$ & & $82 \pi$ & 5 & $\pi$ & & 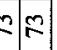 \\
\hline 8) & $\dot{R}$ & $\dot{i}$ & i & 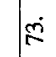 & 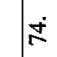 & $n$ & 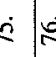 & $\therefore$ & & $\dot{0} \Omega^{\circ}$ & $\dot{\infty}$ & & $\infty=$ & $\dot{f}$ & $\dot{0}$ & & $\dot{\infty} \infty$ \\
\hline
\end{tabular}


As mentioned above, there are similarities in the artifacts of the Pazyryk barrows (in the Altai) and the Seven Brothers barrows (in Europe). The histogram of the distribution of the ${ }^{14} \mathrm{C}$ dates for these groups is presented in Figure 4 from which one can see that the range of the ${ }^{14} \mathrm{C}$ dates is similar which is consistent with the archaeological point of view.

There is a growing number of ${ }^{14} \mathrm{C}$ dates for the European Scythian barrows produced during the last decade allowing the opportunity to compare the dates for the royal European Scythian barrows: the Seven Brothers, Solokha and Chertomlyk. The histogram of the distribution of the ${ }^{14} \mathrm{C}$ dates for these is presented in Figure 5. The tombs can be ranged on the relative time scale as follows: the Seven Brothers, Solokha and Chertomlyk, which does not contradict the archaeological data.

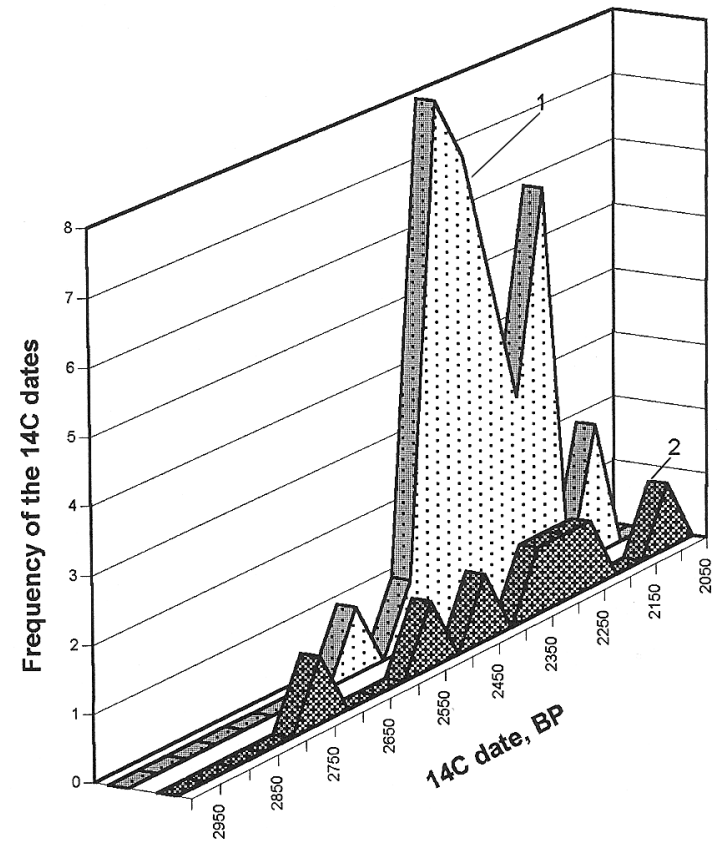

Figure 4 Histogram of the distribution of ${ }^{14} \mathrm{C}$ dates for the Pazyryk group barrows and the Seven Brothers barrows: $1=$ the Pazyryk group barrows, 2 = the Seven Brothers barrows.

\section{DISCUSSION}

The large territory of the Eurasian Steppe belt is populated by a mosaic of nomadic cultures belong to the Scythian epoch which have different names in different regions: Scythians in Europe, Sauromatians in the Lower Volga and Caspian Sea, Southern Ural regions, Tasmola and Saka cultures in Western Kazakhstan, Maiemir and Razyryk cultures in the Sayan-Altai, Tagar culture in Southern Siberia, Aldy-bel' cultures in Central Asia (Figure 1). For a long time, different approaches to the chronology of these cultures were taken, caused by the lack of ${ }^{14} \mathrm{C}$ dates for the European Scythian monuments, the chronology of which was based on archaeological analogies with different imported objects. The majority of European Scythian monuments were excavated before ${ }^{14} \mathrm{C}$ dating was available. The monuments of the Asian territory contained material suitable for ${ }^{14} \mathrm{C}$ dating, mostly the remains of wood from the barrows' construction. The dating of the monuments of Southern Siberia, 
Central Asia and Sayan-Altay regions began in the 1960s. Now, with accelerator mass spectrometry (AMS), ${ }^{14} \mathrm{C}$ dates for materials from the museum collections can be produced. Dating of the European Scythian monuments began in the 1990s. A representative series including over $200{ }^{14} \mathrm{C}$ determinations for the eastern and western parts of the Great Eurasian steppe Scythian monuments belonging to different time periods allows a comparison of their chronological position on a unified ${ }^{14} \mathrm{C}$ time scale. The histogram of the distribution of all ${ }^{14} \mathrm{C}$ dates for both the eastern and western parts of Eurasian steppe is presented in Figure 6. As one can see from this figure, the beginning of the Scythian cultures in Europe fall some hundreds of years later than in Asia, which does not contradict the most recent archaeological theories. The addition of the ${ }^{14} \mathrm{C}$ dates for the Chernogorovsk type monuments in Europe will allow a refinement of this comparison.

Together, the ${ }^{14} \mathrm{C}$ chronology of the Scythian monuments for the different time periods is consistent with the archaeological theories as can be seen in Tables 1-3 and the results mentioned above. The results on the absolute/calendar chronology are not so important in this comparison.

For the most part, the monuments for the Great Steppe belt: Kazakhstan, the Southern Ural, and Lower Volga River regions, have not been dated before now, as can be seen in Figure 1. This fact makes it difficult to compare chronologically the nomadic cultures of the Scythian epoch over the whole territory of Eurasia. It is hoped that these gaps will be filled in the future.

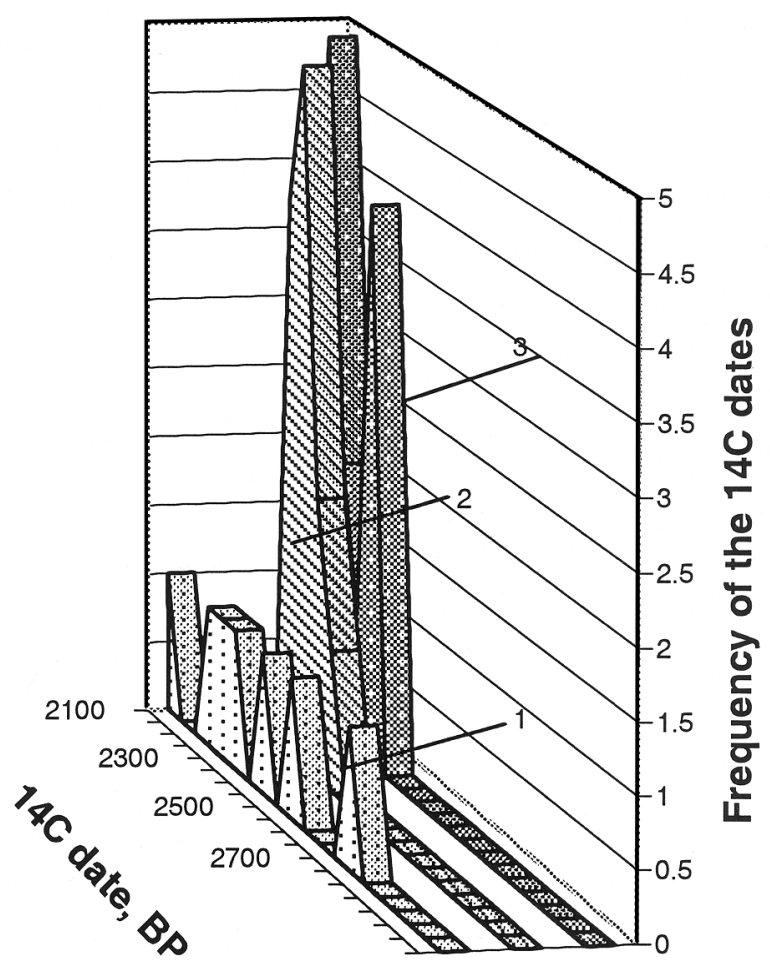

Figure 5 Histogram of the distribution of ${ }^{14} \mathrm{C}$ dates for the Royal barrows of Europe. $1=$ The Seven Brothers barrows, 2 = the Solokha barrow, $3=$ the Chertomlyk barrows. 


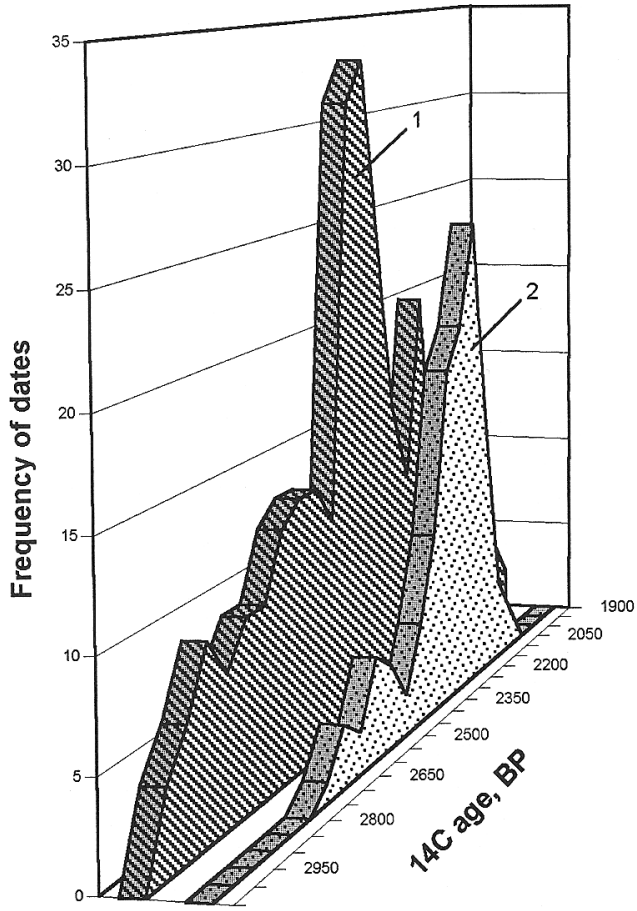

Figure 6 Histogram of the distribution of all ${ }^{14} \mathrm{C}$ dates for the Scythian time monuments belong to the 1 st-3rd periods for: Asia (1) and Europe (2).

\section{CONCLUSION}

The series of ${ }^{14} \mathrm{C}$ dates for the monuments of the Scythian epoch of Eurasia are consistent with the existing chronological and archaeological theories. The three periods of Scythian history confirmed in this research are in concordance with the categorization suggested by Gryaznov (1979) on the basis of the synchronization and typology of the key monuments: 1) The Arzhan-Chernogorovsk phase: 8th-7th century BC, 2) the Maiemir-Kelermess phase: 7th-6th century BC, and 3) the Pazyryk-Chertomlyk phase: 5th-3rd century BC. The lack of reliable imported objects in the Scythian monuments of Central Asia and Siberia enhances the role of scientific methods including dendrochronology and ${ }^{14} \mathrm{C}$ dating (sometimes incorporating wiggle matching) in defining a unified chronology for these cultures.

\section{ACKNOWLEDGMENT}

This research is supported by INTAS, project No 97-20362.

\section{REFERENCES}

Alekseev AYu. 1992. Scythian chronic (Scythian in the 7th-the 4th century BC: historical archaeological review). St. Petersburg: Petersburg Comstat Press. 210 p. In Russian.

Alekseev AYu. 1996. Scythian Kings and Royal barrows of the 4th-the 5th century BC. Journal of Ancient History 3:99-113. In Russian.

Bokovenko NA. 1987. New sites of early Scythian time in the Western Sayan. The Problems of the Soviet Archaeology. Thesis of the Conference. Moscow: 46-7.
In Russian

Bokovenko NA. 1992. The problem of the origin of the horseman burial tradition in the Southern Siberia. Second historical reading devoted to the MP Gryaznov's memory. Omsk. p 99-100. In Russian.

Bokovenko NA. 1994. The genesis problems of the burial tradition of the early nomadic nobility in the Southern Siberia. Elite barrows of the Eurasian steppe in the Scythian-Sarumathian epoch. St.Petersburg. $\mathrm{p}$ 41-48. In Russian. 
Bokovenko NA, Zadneprovskii YuA. 1992. Early nomads of the Eastern Kazakhstan. In: Rybakov BA and MG Moshkova, editors. Archaeology of the USSR. The Steppe zones Of European part of the USSR in the Scythian-Sarumatian Epoch. Moscow: Nauka. 490 p. In Russian.

Bokovenko NA. 1996. Asian influence on European Scythia. Ancient Civilizations from Scythia to Siberia 3(1):97-122.

Boltrik YuV, Fialko EE. 1995. The burial of the scythian kings in the second-half of the 4th century BC. Archaeology 2:3-13. In Ukrainian.

Bonani G, Hajdas I, Rouff U, Seifert M, Molodin V, S1jusarenko I. 2001. Dendrochronological and radiocarbon dating of the scythian burial place in the Pazyryk valley in the Altai mountains, Southern Siberia. $R a-$ diocarbon. This issue.

Chlenova NL. 1967. The origin and the early history of the Tagar culture tribes. Moscow: Nauka. 298 p. In Russian.

Chlenova NL. 1996. The dating of the burial mound Arzhan in Tuva and its place in the cultural system of the "Scythian world". Herald of Anthropology: 18194. In Russian.

Chugunov KV. 1993. The datings of the Great Pazyryk barrows: new impulse of the old discussion The preservation and the study of the cultural heritage of the Altai. Barnaul: 167-9. In Russian.

Chugunov KV. 1994. The investigation of the burial-funeral tradition of the Dogee-Baary-2 complex in Tuva. Elite barrows of the Eurasian steppe in the ScythianSarumathian epoch. St. Petersburg. p 195-9. In Russian.

Chugunov KV. 1996. The burial complex with cenotaph from Tuva. Priest and Shamanism in the Scythian epoch. St. Petersburg. p 69-80. In Russian.

Chugunov KV. 1999. The periodization of the Aldy-Bel culture in Tuva and its final stage. The Results of the study of the Altai and neighboring territories. Barnaul. p 234-7. In Russian.

Dergachev VA, Vasiliev SS, Sementsov AA, Zaitseva GI, Chugunov KV, Slusarenko IJu. 2001. Dendrochronology and radiocarbon dating methods in archaeological studies of the monuments during the Scythian-Sarmatian time. Radiocarbon. This issue.

Dudarev SL. 1995. To the problem of the interaction of the tribes of the Northern Caucasus with the early nomads during pre-scythian epoch. Armavir. 50 p. In Russian.

Dudarev SL. 1998. To the question about the place of the Kimmerian complexes from the Western Asia in the system of the chronological and cultural connections in the Northern Black Sea region, Caucasus and the Eastern European regions. Journal of Ancient History: 77-93. In Russian.

Dudarev SL. 1999. The Northern Caucasus and early nomads in the Scythian epoch (the 9th-the first half of the 7th c. BC). Doctoral dissertation. Moscow. 38 p.

Dudarev SL. 1999. The interaction of the tribes of the Northern Caucasus and the Southern-Eastern Europe during the pre-scythian time (the 9th-first half of the 7th c. BC). Armavir. 400 p. In Russian.

Erlikh VP. 1994. To the initial of the early scythian complex. Moscow. 196 p. In Russian.

Kiselev SV. 1951.The ancient history of the Southern Siberia. 643 p. In Russian.

Galanina LM. 1997. The Kelermess barrows. The Royal burials of the early Scythian epoch. Steppe population of Eurasia 1. Moscow. 270 p. In Russian and German.

Grach AD. 1980. The Ancient nomads of central Asia. Moscow: Nauka. 256 p. In Russian.

Grach AD. 1983. The historical-cultural population of the Early Scythian epoch in central Asia. Archaeological Journal of the State Hermitage Museum 23:3042. In Russian.

Gryaznov MP. 1979. On the unite process of the development of the Scythian-Siberian cultures. The problems of the Scythian-Siberian historical-cultural coтmunity. Kemerovo. p 4-7. In Russian.

Gryaznov MP. 1980. Arzhan. Leningrad: Nauka. 62 p. In Russian.

Gryaznov MP. 1983. The initial phase of development of the Scythian-Siberian culture. Archeology of South Siberia. Kemerovo. p 3-18. In Russian.

Klochko VI, Murzin VYu. 1989. About the chronology of the Chrnogorovsk-type antiquities. The problems of the archaeology of the Dnieper River basin. Dnepropetrovsk. p 61-71. In Russian.

Klochko VI, Skori SA. 1993. The Steblev barrow No. 15 near Steblev town in the Poross River basin. Archaeology 2:71-84. In Ukrainian.

Klochko VI, Kovalyukh NN, Skripkin V, Motzenbecker I. 1997. Isotope chronology of the Subotiv settlement. Radiocarbon 40(2):667-73.

Kossack G. 1987. Von den Anfängen des skytho-iranichen Tierstils Skythika. München: Bayerische Akademie der Wissenschaften. Philosophisch-historische Klasse 98:24-86. In German.

Kurochkin GN. 1991. The initial date of the Tagar culture. Problems of the chronology and periodization of the archaeological sites in the Southern Siberia. Barnaul. p 103-5. In Russian.

Kyzlasov LR. 1979. Ancient Tuva. Moscow: Moscow University Press. 207 p. In Russian.

Marsadolov LS. 1984. On the sequence of the 5th Pazyryk barrows in the Altai. Archaeological Journal of the State Hermitage Museum 25:90-8. In Russian.

Marsadolov LS. 1987. The chronological comparison of the Pazyryk and the Seven Brothers barrows. Archaeological Journal of the State Hermitage Museum 28: 30-7. In Russian.

Marsadolov LS. 1996. The history and the results of the research of the archaeological monuments of the 8th4th c. BC in the Altai (from the initial stage up to the 
1980). St. Petersburg. 88 p. In Russian.

Marsadolov LS, Zaitseva GI, Lebedeva LM. 1994. The correlation of the dendrochronological and radiocarbon determinations for the Great barrows of the Sayan-Altai. Elite barrows of the Eurasian steppe in the Scythian-Sarumathian epoch. St. Petersburg. p 141-56. In Russian.

Marsadolov LS, Zaitseva GI, Sementsov AA, Lebedeva LM. 1996. The Possibility of the radiocarbon dating for the connection of the floating tree-ring scale to the calendar time. Radiocarbon and Archaeology. St. Petersburg. 1:24-32. In Russian.

McCormac FG, Reimer PJ, Mallory JP, Marsadolov LS. 2001. The date of the Pazyryk tombs. Radiocarbon: this issue.

Monakhov SYu. 1999. The Greek amphorae in the Black Sea region. The ceramic complex of the 7th -2 nd $c$. $B C$. Saratov: Saratov University Press. 678 p. In Russian.

[NHA] Notes in the History of Art. 1991. A special issue on the dating of Pazyryk. New York. 10(4):2-36.

Polin SV. 1994. On the chronology of the Cimmerian antiquities. Simpozion international. Masivul Traco-cimerian. Probleme actuale/Chisinau. p 56-60.

Polin SV. 1998. About the chronology of the early Scythian culture (according to I N Medvedskaya). Journal of Russian Archaeology 4:50-63. In Russian.

Raev BA. 1989. Alanian in the Eurasian steppe: the Eastthe West Scythia and Bosporus. Proceeding of the conference devoted to the memory of M I Rostovzev. Novocherkassk. p 116-7. In Russian.

Savinov DG. 1991. The possibilities of the synchronization of the written and archaeological data to the study of the Scythian-Sauromatian cultures in the Southern Siberia. Problems of the chronology and periodization of the archaeological cultures of the Southern Siberia. Barnaul. p 93-6. In Russian.

Savinov DG. 1993. To the study of the ethnic-political history of the people of the Southern Siberia during the Scythian epoch. Historical Enthography. St. Petersburg. p 128-35. In Russian.

Sementsov AA, Zaitseva GI, Görsdorf J, Nagler A, Parzinger G, Bokovenko NA, Chugunov KV, Lebedeva LM. 1998. Chronology of the burial finds from the Scythian monuments in Southern Siberia and Central Asia. Radiocarbon 40(2):713-20.

Volchak SB, Mamontov VI, Sazonov AA. 1996. The early sites of the Chernogorovsk type in the Western Europe: the origin and the chronology. Historical-archaeological Almanakh. Armavir, Moscow 2: 23-44. In Russian.

Zaitseva GI, Possnert G, Alekseev AYu, Dergachev VA. 1998. The first ${ }^{14} \mathrm{C}$ dating of monuments in European Scythia. Radiocarbon 40(2):767-75.

Zaitseva GI, Vasiliev SS, Marsadolov LS, Van der Plicht J, Sementsov AA, Dergachev VA, Lebedeva LM. 1998. A tree-ring and ${ }^{14} \mathrm{C}$ chronology of the Key Sayan-Altai Monuments. Radiocarbon 40(2):571-80. 